\section{GEOSPHERE}

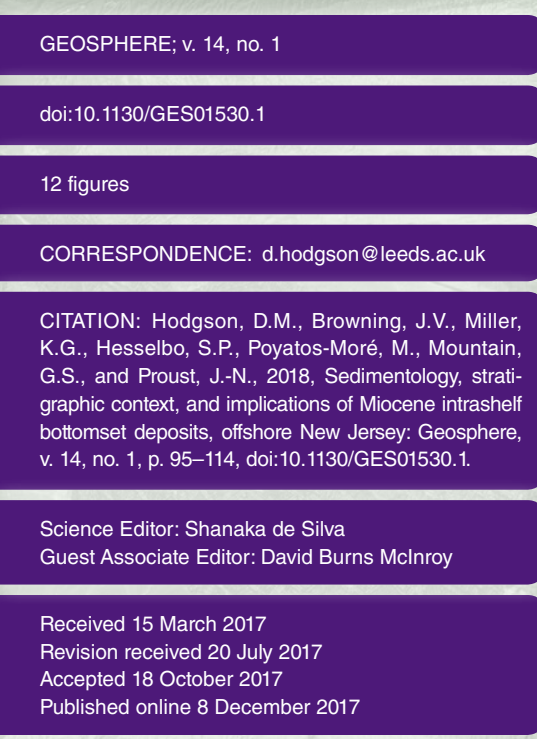

Published online 8 December 201

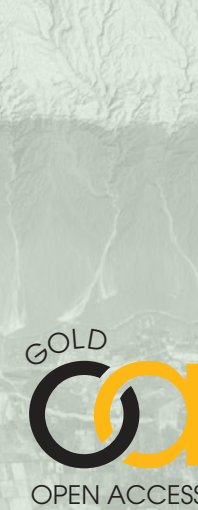

OPEN ACCESS

THE GEOLOGICAL SOCIETY OF AMERICA ${ }^{\circledR}$

This paper is published under the terms of the CC-BY license.

() 2017 The Authors

\title{
Sedimentology, stratigraphic context, and implications of Miocene intrashelf bottomset deposits, offshore New Jersey
}

D.M. Hodgson', J.V. Browning' ${ }^{2}$, K.G. Miller², S.P. Hesselbo ${ }^{3}$, M. Poyatos-Moré ${ }^{4}$, G.S. Mountain², and J.-N. Proust ${ }^{5}$ ${ }^{1}$ Stratigraphy Group, School of Earth and Environment, University of Leeds, Leeds LS2 9JT, UK 2Department of Earth and Planetary Sciences, Rutgers University, Piscataway, New Jersey 08854, USA ${ }^{3}$ Camborne School of Mines, University of Exeter, Penryn Campus, Penryn, Cornwall TR10 9FE, UK

${ }^{5}$ Géosciences Rennes, CNRS, Université de Rennes, Campus de Beaulieu, 35042 Rennes, France

\section{ABSTRACT}

Drilling of intrashelf Miocene clinothems onshore and offshore New Jersey has provided better understanding of their topset and foreset deposits, but the sedimentology and stratigraphy of their bottomset deposits have not been documented in detail. Three coreholes (Sites M27-M29), collected during Integrated Ocean Drilling Program (IODP) Expedition 313, intersect multiple bottomset deposits, and their analysis helps to refine sequence stratigraphic interpretations and process response models for intrashelf clinothems. At Site M29, the most downdip location, chronostratigraphically well-constrained bottomset deposits follow a repeated stratigraphic motif. Coarse-grained glauconitic quartz sand packages abruptly overlie deeply burrowed surfaces. Typically, these packages coarsen then fine upwards and pass upward into bioturbated siltstones. These coarse sand beds are amalgamated and poorly sorted and contain thin-walled shells, benthic foraminifera, and extrabasinal clasts, consistent with an interpretation of debrites. The sedimentology and mounded seismic character of these packages support interpretation as debrite-dominated lobe complexes. Farther updip, at Site M28, the same chronostratigraphic units are amalgamated, with the absence of bioturbated silts pointing to more erosion in proximal locations. Graded sandstones and dune-scale cross-bedding in the younger sequences in Site M28 indicate deposition from turbidity currents and channelization. The sharp base of each package is interpreted as a sequence boundary, with a period of erosion and sediment bypass evidenced by the burrowed surface, and the coarse-grained debritic and turbiditic deposits representing the lowstand systems tract. The overlying fine-grained deposits are interpreted as the combined transgressive and highstand systems tract deposits and contain the deepwater equivalent of the maximum flooding surface. The variety in thickness and grain-size trends in the coarse-grained bottomset packages point to an autogenic control, through compensational stacking of lobes and lobe complexes. However, the large-scale stratigraphic organization of the bottomset deposits and the coarse-grained immature extrabasinal and reworked glauconitic detritus point to external controls, likely a combination of relative sea-level fall and waxing-and-waning cycles of sediment supply. This study demonstrates that large amounts of sediment gravity-flow deposits can be generated in relatively shallow $\left(\sim 100-200 \mathrm{~m}\right.$ deep) and low-gradient $\left(\sim 1^{\circ}-4^{\circ}\right)$ clinothems that prograded across a deep continental shelf. This physiography likely led to the dominance of debris flow deposits due to the short transport distance limiting transformation to low-concentration turbidity currents.

\section{口 INTRODUCTION}

Seismic sequences that prograde seaward, with geometrically defined topset, foreset, and bottomset deposits (Fig. 1), bounded by surfaces with a distinct sigmoidal (clinoform) geometry (e.g., Vail, 1987; Van Wagoner et al., 1987) are termed clinothems (e.g., Rich, 1951; Plink-Björklund and Steel, 2002; Johannessen and Steel, 2005; Miller et al., 2013a, 2013b). Depending on the geological setting and data sets examined, clinothem-bounding surfaces can be maximum flooding surfaces (Carvajal and Steel, 2006) or sequence boundaries (Miller et al., 2013a). Several scales of progressively larger-scale clinothems can prograde synchronously along a shoreline-to-abyssal plain transect (Fig. 1). The bottomset of one clinothem in an updip location corresponds to the topset of a larger-scale clinothem in a downdip location, meaning that these compound clinothems are genetically and morphologically linked (Swenson et al., 2005; Helland-Hansen and Hampson, 2009; Henriksen et al., 2009; Fig. 1). Objective description of the depositional architecture of compound clinothems requires recognition of reflector terminations on seismic profiles (onlap, downlap, erosional truncations, and toplap or offlap; e.g., Vail et al., 1977; Mitchum et al., 1977) and patterns on logs and in coreholes (Van Wagoner et al., 1987; Carvajal and Steel, 2009; Carvajal et al., 2009; Miller et al., 2013b). This approach permits identification of key stratal surfaces (sequence boundaries, transgressive surfaces, and maximum flooding surfaces) and stacking patterns of parasequences (Vail, 1987; Van Wagoner et al., 1987; Posamentier and Vail, 1988; Posamentier et al., 1988), and subdivision of depositional sequences into different systems tracts: lowstand (LST), transgressive (TST), highstand (HST; Vail, 1987; Van Wagoner et al., 1987; Posamentier and Vail, 1988; Posamentier et al., 1988), and falling stage (FSST) 
(Plint and Nummendal, 2000). Commonly, systems tracts are tied to relative sea-level curves (Vail, 1987; Van Wagoner et al., 1987; Posamentier and Vail, 1988; Posamentier et al., 1988; Coe, 2003; Catuneanu, 2006); however, stratal surfaces and systems tracts can be objectively defined irrespective of baselevel changes (Neal and Abreu, 2009; Miller et al., 2013a). In deepwater settings (below storm weather wave base), the seismic criteria for definition of sequence bounding unconformities is lost (or becomes cryptic) basinward, which led Mitchum et al. (1977) to coin the term "correlative conformity" for the surface traced beyond the unconformity. Recognition and interpretation of the LST is often equivocal because of the uncertainties in placement of its base versus that of the FSST (Coe, 2003; Hodgson et al., 2016) and the varied facies it contains (van der Merwe et al., 2010).
The interaction between sediment supply, accommodation, and process regime needs to be assessed in order to understand the depositional architecture of clinothems and the stratigraphic evolution of basin margins (e.g., Vail et al., 1977; Posamentier and Vail, 1988; Van Wagoner et al., 1988; Galloway, 1989; Christie-Blick and Driscoll, 1995; Martinsen and Helland-Hansen, 1995; Burgess and Hovius, 1998; Steel and Olsen, 2002; Johannessen and Steel, 2005; Carvajal and Steel, 2006; Dixon et al., 2012b; Burgess and Prince, 2015; Jones et al., 2015). Exhumed clinothem rollovers have proven valuable in the assessment of process interactions in the critical zone between shallow-marine currents (interactions of wave, river, and tide processes) and gravity-driven processes below storm weather wave base (e.g., Plink-Björklund and Steel, 2002; Mellere et al., 2002; Uroza and Steel, 2008; Carvajal and Steel, 2009; 
Dixon et al., 2012a; Jones et al., 2013; Poyatos-Moré et al., 2016). However, outcrop and well coverage is generally limited, and detailed documentation of the sedimentology and stratigraphy of individual clinothems from topset, through foreset, to bottomset settings is rare (e.g., Carvajal and Steel, 2009; Carvajal et al., 2009; Wild et al., 2009; Grundvåg et al., 2014; Prélat et al., 2015; Koo et al., 2016). Therefore, to unravel the interplay of these different controls, detailed observations and data across multiple successive clinothems and a range of scales are needed. This requires large integrated data sets with well-mapped clinothems that have good chronostratigraphic constraints and detailed sedimentary facies information.

A unique subsurface data set collected offshore New Jersey (Integrated Ocean Drilling Program [IODP] Expedition 313, Sites M27, M28, and M29; Fig. 2 intersected the topset, foreset, and bottomset deposits of multiple successive Miocene clinothems (Mountain et al., 2010). The process sedimentology and stratigraphy preserved in clinoform topsets are well constrained by onshore and offshore coreholes (Miller et al., 1997), and the foreset deposits have been used to help refine sequence stratigraphic models (Miller et al., 2013a). However, the character of the bottomset deposits has been poorly constrained because they are absent from coreholes drilled on the modern coastal plain, and coreholes drilled on the modern shelf edge and slope (Mountain et al., 1994; Christie-Blick et al., 2003) largely provided muddy mass-transport deposits and homogeneous mudstone-dominated facies successions (Hesselbo and Huggett, 2001; McHugh et al., 2002). The aim of this paper is to document in detai the sedimentology and stratigraphic record of the Miocene clinothem bottomset deposits in an overall sequence stratigraphic framework attained by Expedition 313. We address the following objectives: (1) to describe and interpret the process sedimentology of bottomset deposits; (2) to develop depositional environment models for intrashelf clinothems; (3) to consider these deposits in a sequence stratigraphic framework; and (4) to discuss the controls on the timing of sediment supply from shallow $(<100 \mathrm{~m})$ to deep water $(100-200 \mathrm{~m})$ in this setting.

\section{- GEOLOGICAL SETTING AND PREVIOUS WORK}

The New Jersey-Delaware-Maryland Atlantic passive margin is an idea natural laboratory for understanding the interaction of sediment supply, accommodation, and process regime due to the wealth of previously collected data (summarized in Mountain et al., 2010). Late Triassic to earliest Jurassic rifting (ca. 230-198 Ma) was followed by uplift and seafloor spreading beginning prior to the Bajocian (ca. $175 \mathrm{Ma}$; Middle Jurassic), with the likely onset of opening off the southeast U.S. by ca. $200 \mathrm{Ma}$ and progressing northward to the U.S. middle Atlantic margin (Withjack et al., 1998). This was followed by thermal subsidence on the margin associated with sediment loading and flexure (Watts and Steckler, 1979; Reynolds et al., 1991). The Jurassic succession comprises 8-12 km of shallow-water limestones and mudstones, and a barrier reef complex fringed the margin until the mid-Cretaceous (Poag, 1985). Accumulation rates were generally low $(<20 \mathrm{~m} / \mathrm{m}$.y.) during dominantly carbonate deposition in the Late Cretaceous to Paleogene (Poag, 1985). A major transition from carbonate ramp to starved siliciclastic sedimentation occurred in the late middle Eocene to earliest Oligocene in response to global and regional cooling (Miller and Snyder, 1997). Sedimentation rates increased dramatically in the late Oligocene to Miocene (Poag, 1985; Miller and Snyder, 1997; Browning et al., 2013), resulting in a siliciclastic sedimentary prism that comprises multiple clinothems that prograded above a wide $(\sim 150 \mathrm{~km})$ and deep $(100-400 \mathrm{~m})$ low-gradient shelf. These clinothems were first identified as "deltas" (Schlee, 1981). However, deltas are much smaller and will form part of the topsets (Fig. 1). Intrashelf clinothems, which form a basinward-thickening shelf prism (Patruno et al. 2015), are part of a hierarchy of clinoform scales (Fig. 1) and are similar in scale to other systems where the topsets are referred to as the shelf, the foresets as the slope, and the bottomsets as the basin floor (e.g., Carvajal et al., 2009). These terms may be appropriate when there is not an observable continental shelf break. In the case of the New Jersey margin, however, we prefer the descriptive topset-foreset-bottomset terminology because these compound clinoforms are demonstrably located on the shelf (Fig. 1) with a shelf break and continental slope and rise seaward, and are therefore building the shelf segment of the basin (sedimentary shelves of Helland-Hansen et al. [2012]). The topset-foreset-bottomset nomenclature has been employed for intermediate-scale clinoforms that developed on deep shelves (e.g., Steel and Olsen, 2002; Anell et al., 2014; Patruno et al., 2015; Pellegrini et al., 2017) or in lakes (e.g., Fongngern et al., 2016).

The seismic stratigraphy of the Miocene and younger margin deposits is characterized by the intrashelf clinothems (e.g., Monteverde et al., 2008). The clinothems generally prograde, with lower to lowermost middle Miocene sequences found beneath the modern inner-middle continental shelf, middle Miocene sequences beneath the modern middle shelf, and upper Miocene and younger beneath the modern outer shelf (Greenlee et al., 1992). Sequences are named according to their basal reflector boundary, for example sequence m5.2 lies on reflector m5.2 (Monteverde et al., 2008; Monteverde, 2008; Mountain et al., 2010; Fig. 3). IODP Expedition 313 recovered Oligocene to Holocene siliciclastic sediments from three coreholes at $\sim 35 \mathrm{~m}$ present depth (Sites M27, M28, and M29; Fig. 2) on the inner-middle continental shelf of New Jersey (Mountain et al., 2010). Core recovery for the target sequences was $\sim 80 \%$, and geophysical logs were obtained at all three sites (Fig. 3).

Seismic profiles (Fig. 3) show that clinothems vary from 100 to $200 \mathrm{~m}$ in thickness and that foresets dip seaward $1^{\circ}-4^{\circ}$ and are $5-15 \mathrm{~km}$ in basinward length. Two-dimensional backstripping, accounting for the effects of compaction and loading, restores the clinoforms to their original thickness (Steckler et al., 1999). Reconstructions indicate that the height on the m5.8, m5.6, and m5.2 clinothems (Fig. 3) was $\sim 50, \sim 100$, and $\sim 100 \mathrm{~m}$, respectively (Kominz et al., 2016), with calculated foreset gradients of $0.5^{\circ}, 0.7^{\circ}$, and $0.8^{\circ}$, respectively. Two-dimensional backstripping also shows that the Late Cretaceous to Miocene structural continental shelf break was at several hundred meters water depth, well seaward (>75 km) of these clinothems (Steckler et al., 1999; Mountain et al., 2010; Miller et al., 2013b, Kominz et al., 2016). Therefore, the 


New Jersey Sea-Level Transect
Seismic Profiles
$\quad$ CH0698
$-\quad$ Ew9009
Oc270
Existing Drillsites
$\quad$ DSDP
$\bullet \quad$ AMCOR
$9030 \quad$ ODP Leg 150, 150X
$10720 \quad$ ODP Leg 174A, 174AX
M27 $0 \quad$ IODP Leg 313

T

1

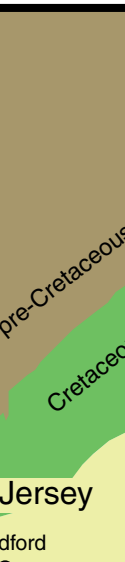

$74^{\circ}$

\section{New Jersey}
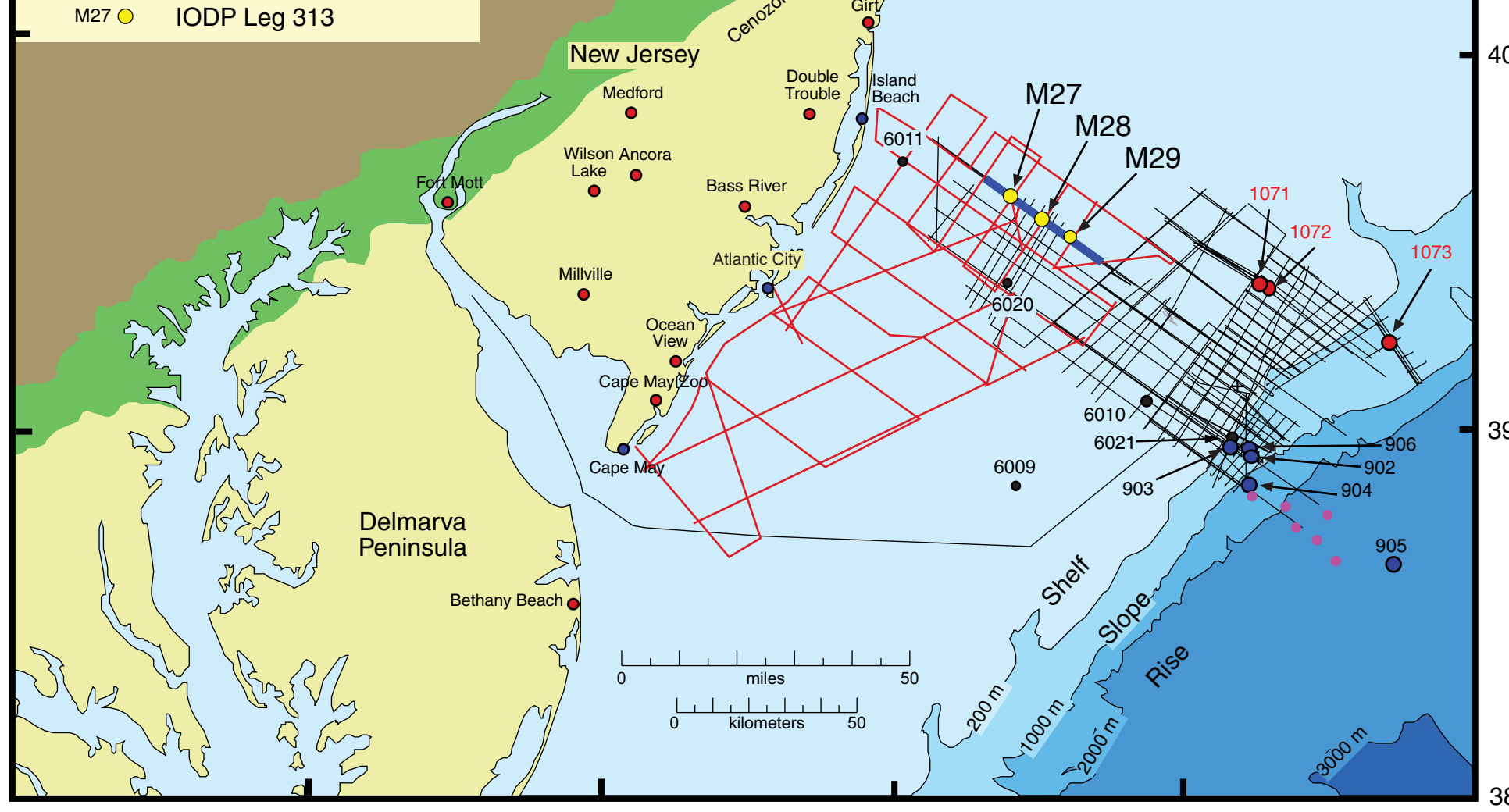

Nist
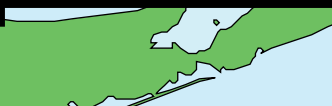

Figure 2. Generalized bathymetric location map of the New Jersey-Mid-Atlantic margin sea-level transect showing three generations of multichannel seismic data (cruises R/V Ewing Ew9009, R/V Oceanus Oc270, and R/V Cape Hatteras CH0698), onshore and offshore coreholes drilled by Atlantic Margin Coring Project (black dots; AMCOR; Hathaway et al., 1979), the Ocean Drilling Program (ODP: blue dots for ODP Legs 150 and 150X; red dots for ODP Legs 174A and 174X), the Integrated Ocean Drilling Program (IODP; yellow dots for IODP Exp 313), and the Deep Sea Drilling Project (DSDP; purple dots). The blue line is the position of the multichannel seismic profile shown in Figure 3. 


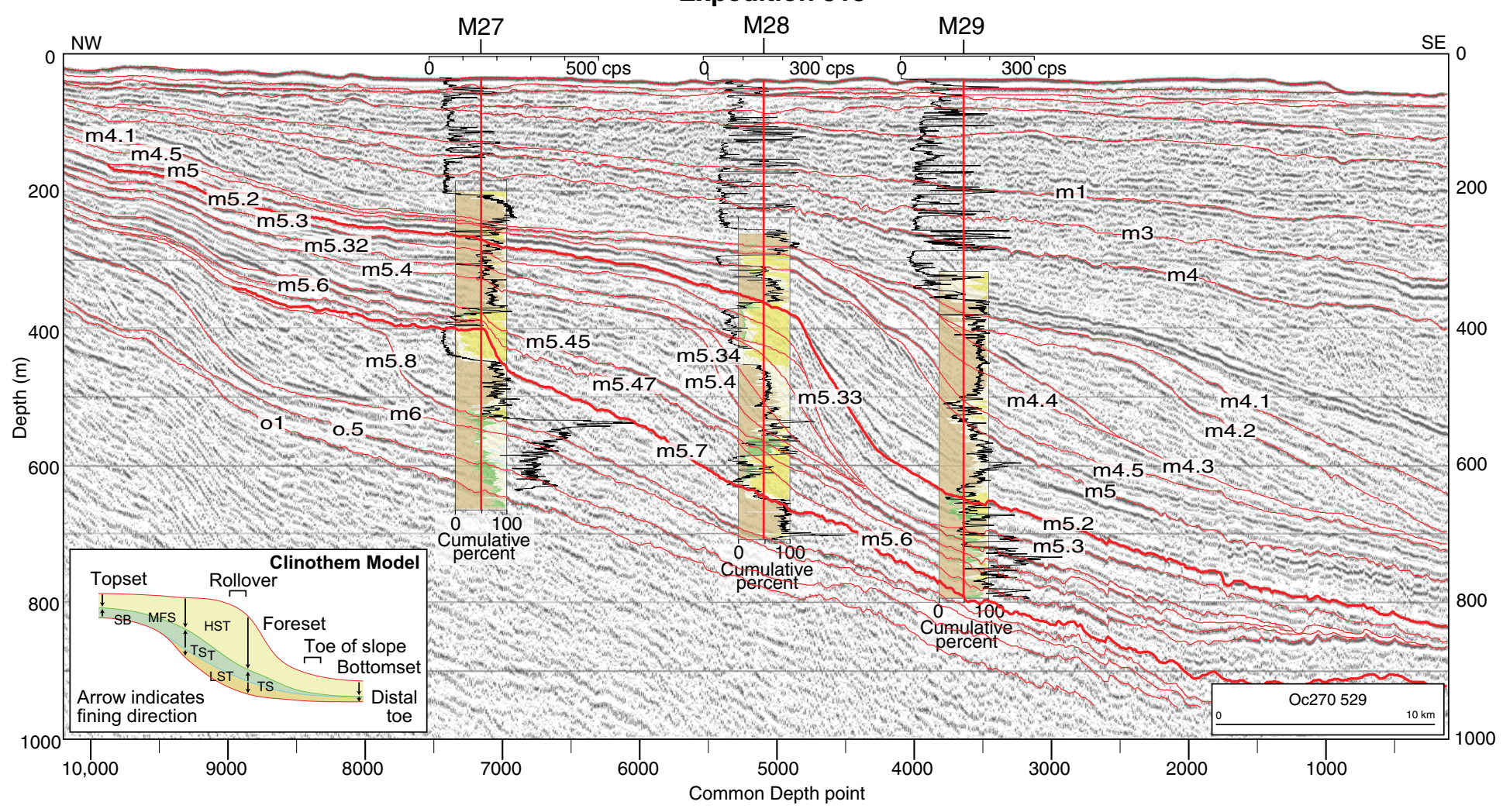

Figure 3. Multichannel seismic profile Oc270 529 (R/V Oceanus) in region of Integrated Ocean Drilling Program Expedition 313 (offshore New Jersey) providing a long dip profile from northwest to southeast. Sites M27-M29 are located on this line. Refer to Figure $\mathbf{2}$ for location of the profile. Vertical axis is depth in meters below sea level obtained using a revised velocity-depth function (Mountain and Monteverde, 2012); horizontal axis is common depth points ( $1 \mathrm{cdp}=6.25 \mathrm{~m}$ ); horizontal scale (in $\mathrm{km}$ ) is given on lower right. Red lines show major seismic sequence boundaries (labels beginning with " $\mathrm{m}$ ") and select intrasequence reflectors $(01,0.5)$. Superimposed are the coarse fraction cumulative percent lithology (brown-mud; light yellow-fine quartz sand; dark yellow-medium-coarse quartz sand; green-glauconite sand) and downhole gamma logs (black line; in counts per second [cps]) as described in Miller et al. (2013b). Inset: Clinothem model (from Miller et al., 2013a); arrows point in the fining (deepening) direction. SB-sequence boundary (red line); TS-transgressive surface (blue line); MFS-maximum flooding surface (green line); LSTlowstand systems tract (brown); TST-transgressive systems tracts (green); and HST-highstand systems tract (light green).

seaward progradation of the Miocene clinothems was entirely confined to the continental shelf. The intrashelf sedimentary prism reached the modern outer continental shelf in the late Miocene and the structural shelf-edge break in the Pleistocene (Fulthorpe and Austin, 1998; Steckler et al., 1999).

Cores drilled by ODP Legs 150, 174, 150X, and 174AX through onshore and offshore New Jersey clinothems have provided significant advances in understanding the timing and magnitude of relative sea-level change in shallowmarine settings through much of the Late Cretaceous and Cenozoic (e.g., Miller et al., 2005). However, onshore drilling of topset deposits recovered sequences that comprise mainly TST and HST deposits. The facies associations in these onshore cores primarily comprise transgressive fining-upward packages of sand and silt overlain by a regressive coarsening- and thickening-upward succession of bioturbated silt and quartz-rich sand. These are interpreted as mixed wave-dominated and river-influenced (Wr of Vakarelov and Ainsworth [2013]) offshore to shoreface deposits (Miller et al., 1997). Miocene clinothem bottomset deposits, and facies representing deepwater (>100 m paleodepth) shelfal environments, were not sampled by previous drilling projects. In part, IODP Expedition 313 was designed to fill this gap (Mountain et al., 2010).

Expedition 313 results showed 25 regionally mapped Oligocene to Miocene seismic surfaces that correlate to abrupt sedimentary facies changes 
in the coreholes (Mountain et al., 2010; Miller et al., 2013b). Sequences were dated with a resolution of \pm 0.25 to $\pm 0.5 \mathrm{~m}$.y. by integrating nannofossil, planktonic foraminiferal, and dinocyst biostratigraphy with Sr-isotopic stratigraphy (Browning et al., 2013). Here, we focus on lower to middle Miocene sediments deposited in intrashelfal base-of-slope to distal bottomset locations from sequences m5.8 (20.0-19.5 Ma; Browning et al., 2013) to m5.3 (16.3-15.7 Ma Browning et al., 2013) (Fig. 3).

\section{METHODS}

The three research cores collected during IODP Expedition 313 are along a dip transect that runs parallel to several existing seismic profiles (Figs. 2 and 3). Sixteen lower to middle Miocene (ca. 23-13 Ma) seismic sequence boundaries were recognized in profiles and correlated to the IODP Expedition 313 sites using a velocity-depth function developed from stacking velocities of nearby profiles (Mountain et al., 2010; Mountain and Monteverde, 2012; Miller et al., 2013a). The reflection seismic data have a vertical resolution of $\sim 5 \mathrm{~m}$, and were shot by the R/V Oceanus cruise Oc270 in 1995 with a 48-channel generator injector gun and HiRes (http://www.seimaxtech.com/) equipment (Mille et al., 2013b). Sequence boundaries are recognized on seismic reflection profiles by reflector terminations: onlap, erosional truncation, downlap, and toplap (Vail et al., 1977; Mitchum et al., 1977). Seismically interpreted sequence boundaries correlate well with sequence boundaries recognized on the basis of physical stratigraphy and sedimentological character in the Expedition 313 cores, indicating that impedance contrasts across changes in stratal patterns are indicative of sequence boundary locations (Miller et al., 2013b; Fig. 3). Here, we focus on sequences m5.3-m5.8 because their topset, foreset, and bottomset deposits were intersected by the coreholes. In particular, cores from Sites M28 and M29 provide excellent records of bottomset deposits (Figs. 3-5).

Lithologic composition of the $>63 \mu \mathrm{m}$ fraction (very fine sand and coarser) was obtained semiquantitatively. A total of 1727 samples were washed through a $63 \mu \mathrm{m}$ screen, and the percent mud (clay and silt) versus sand was calculated (data are tabulated in Miller et al. [2013a]). The sand fraction was sieved to separate the fine and very fine quartz sand and glauconite sand from the medium and coarser quartz sand and glauconite sand. Percent glauconite, shells, and mica were visually estimated. The data, graphed alongside the lithologic columns, are useful in showing fining- or coarsening-upward trends and stratigraphic trends in the proportion of quartz and glauconite sand that enhance observations in descriptive lithology.

Paleoenvironmental interpretations of lithofacies are based on previous studies of shallow-marine sediments using a wave-dominated shoreline mode (summarized in Mountain et al. [2010]), recognizing upper shoreface (0-5 m), lower shoreface (5-10 m), shoreface-offshore transition (10-30 m), and offshore $(>30 \mathrm{~m}$ ) environments. Benthic foraminiferal biofacies, reported by Mountain et al. (2010) and in greater detail by Katz et al. (2013), provide paleodepth constraints in deeper $(>30 \mathrm{~m}$ ) water following the general paleobathymetric mode of Miller et al. (1997) for coeval onshore New Jersey sections. An important addition to the Miller et al. (1997) benthic foraminifer model is the finding of Uvigerina juncea-dominated biofacies, interpreted as middle neritic or deeper (>75 m), and of high-diversity, low-dominance assemblages with key indicator taxa (e.g., Cibicidoides pachyderma, Hanzawaia mantaensis, and Oridorsalis), interpreted as outer neritic (>100 m) (Mountain et al., 2010; Katz et al., 2013).

\section{SEDIMENTOLOGY}

Here, we focus on sedimentary facies associations found in the lower foreset and bottomset positions, and their interpretation in terms of sedimentary processes and depositional environments. The full range of sedimentary facies and their interpreted depositional environments from analysis of the three coreholes are described by Mountain et al. (2010). Sediments deposited on the bottomset are abundant at the base of the Site M28 (501-611.6 mcd [meters composite depth]) and Site M29 cores (593-746/753.8 mcd) (Figs. 4 and 5), and are of two broad facies association groups: fine grained and coarse grained.

\section{Fine-Grained Facies}

Fine-grained lower foreset and bottomset deposits are found in all three holes. At Site M27, they are only found in cores 168 and 169 (482.4-483.5 and 484.8-485.2 mcd; sequence m5.8). At Site M28, sediments deposited in lower foreset to bottomset settings are found from the transgressive surface of sequence $\mathrm{m} 5.34$ ( $475 \mathrm{mcd}$, core 98 ) down to the base of sequence $\mathrm{m} 5.7$ (611.6 mcd; core 152). Fine-grained facies are rare at Site M28. They are found from the transgressive surface in sequence $\mathrm{m} 5.34(475 \mathrm{mcd}$; core 98$)$ to the base of core 108 ( $\sim 506 \mathrm{mcd})$, from the $\mathrm{m} 5.4$ sequence boundary (512.33 mcd; core 110 down to $\sim 516 \mathrm{mcd}$ (core 111; sequence $\mathrm{m} 5.45$ ), and from $\sim 520 \mathrm{mcd}$ to $\sim 523 \mathrm{mcd}$ (bottom of core 113; sequence m5.45). The fine-grained facies is most common in Site M29 cores.

\section{Description}

Fine-grained successions in lower foreset to bottomset positions form two types of facies. Type 1 is found only in sequence m5.8, with common meterto $10-\mathrm{m}$-thick coarsening- and thickening-upward packages from silt prone to sand prone. These packages comprise dark to pale brown nannofossil-bearing silty clays to clayey silts that are intercalated with thin $(<5 \mathrm{~cm})$ normally and inversely graded and laminated sand and silt beds containing abundant mica and plant debris, sponge spicules, and diatoms (Fig. 6). Abrupt stratigraphic changes in bioturbation intensity range from absent (with carbonate concretions), through moderate with scarce burrows (e.g., Chondrites, Planolites), to intense with backfilled forms (e.g., Teichichnus, Taenidium). 
Site 313-28

Paleodepth

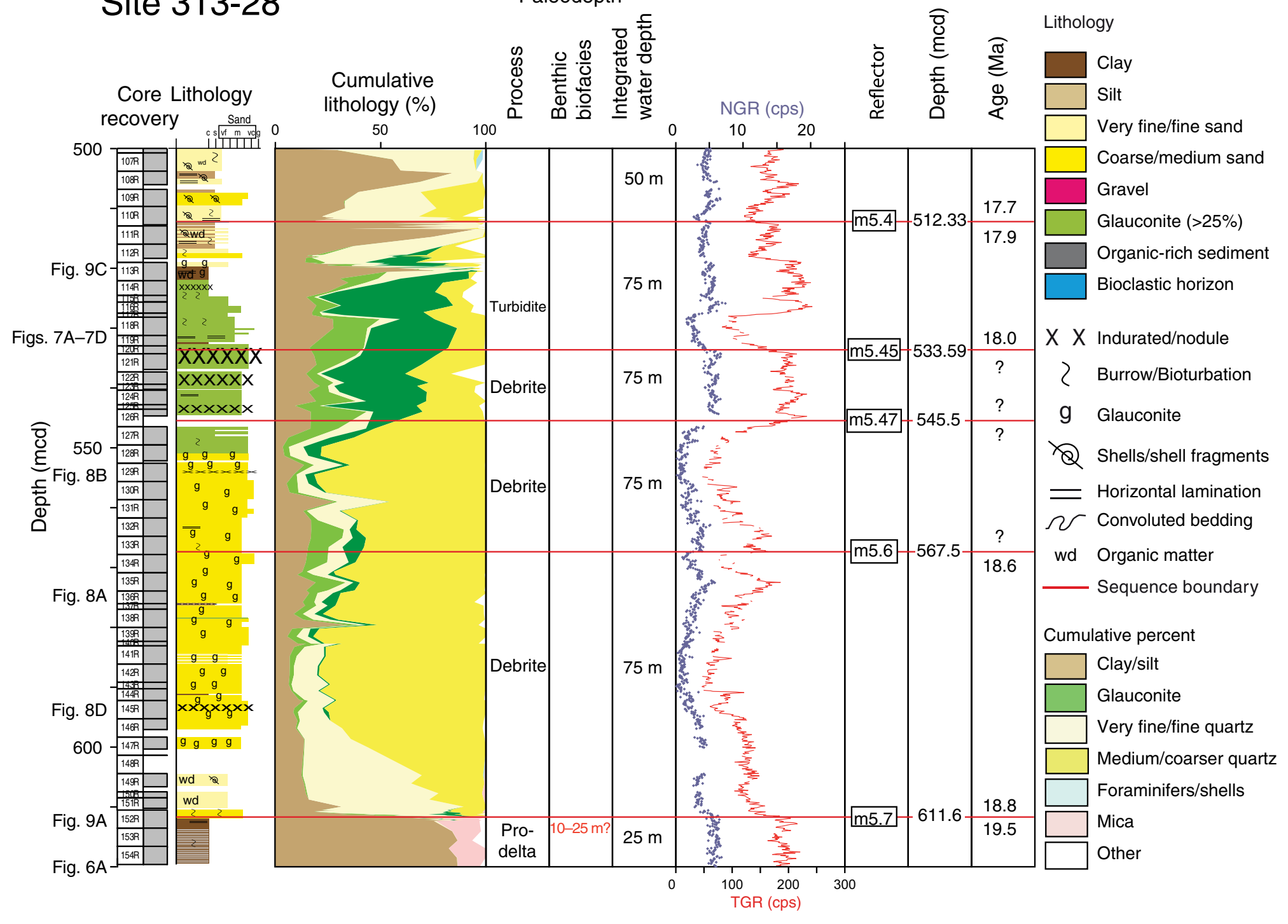

Figure 4. Summary data sheet from Integrated Ocean Drilling Program Expedition 313, Site M28, sequences m5.7-m5.4 (offshore New Jersey); depth is in meters composite depth (mcd). Red horizontal ray (TGR), and those shown as blue dots are mutti-sensor core logger-natural gamma ray (NGR) discrete sample measurements; scale in counts per second (cps). Figure references at left (e.g., Fig. 7A-D) refers to the position where the cores illustrated in those figures are located. Core recovery includes number $(107 R$ to $154 R$, where $R=$ rotary); and core recovery (gray $=$ recovered, white $=$ gap). Lithology grain-size abbreviations: $\mathbf{c}$-clay; s-silt; vf-very fine sand; $\mathbf{m}$-medium sand; vc-very coarse sand; $\mathbf{g}$-gravel. Pro-prodelta. Benthic biofacies column has paleowater depths from Katz et al. (2013) based on benthic foraminiferal biofacies. 
Figure 5. Summary data sheet from Integrated Ocean Drilling Program Expedition 313, Site M29, sequences m5.8-m5.2 (offshore Nerseylidepth is in meters composite depth (mcd). Red horizontal lines represent sequence boundaries (dashed where placement is uncertain), ages for surfaces immediately below and above sequence boundaries are from Browning et al. (2013). Sequence boundaries m5.6 and $m 5.8$ are in coring gaps and depths for those sequence boundaries are shown as ranges (numbers separated by a slash) to show the uncertainty. Sequence m5.47 is cut out at this site. Gamma logs shown in (TGR) are downole as total gamma ray (TGR), and those shown as blue dots are multi-sensor core logger-natural gamma (NGR) discrete sample measureme scale in counts per second (cps). "Fig" refpositon where., Fig. 6B) refers to the position where the cores illustrated in those figures are located. Core recovery includes number (107R to 15aR, where $\mathrm{R}=$ rotary); and core recovery (gray = recovered, white = gap). Lithology grain-size abbreviations. c-Clay, s-silt, vf-very fine sand; $m$-medium sand, vc-very coarse sand; g-gravel. Cumulative lithologr (\%) colors: brown-mud; light yellowfine quartz sand, dark yellow-medium to coarse quartz sand, light green-fine glauconite sand, dark green-coarse glauconite sand; light blue-carbonate (shells and foraminifera); pink-mica. Benthic biofacies column has paleowater depths from Katz et al. (2013) based on benthic foraminiferal biofacies. See Figure 4 for $e x-$
planation of other colors and symbols.
Site 313-29

Core

recovery Lithology

Cumulative

Paleodepth

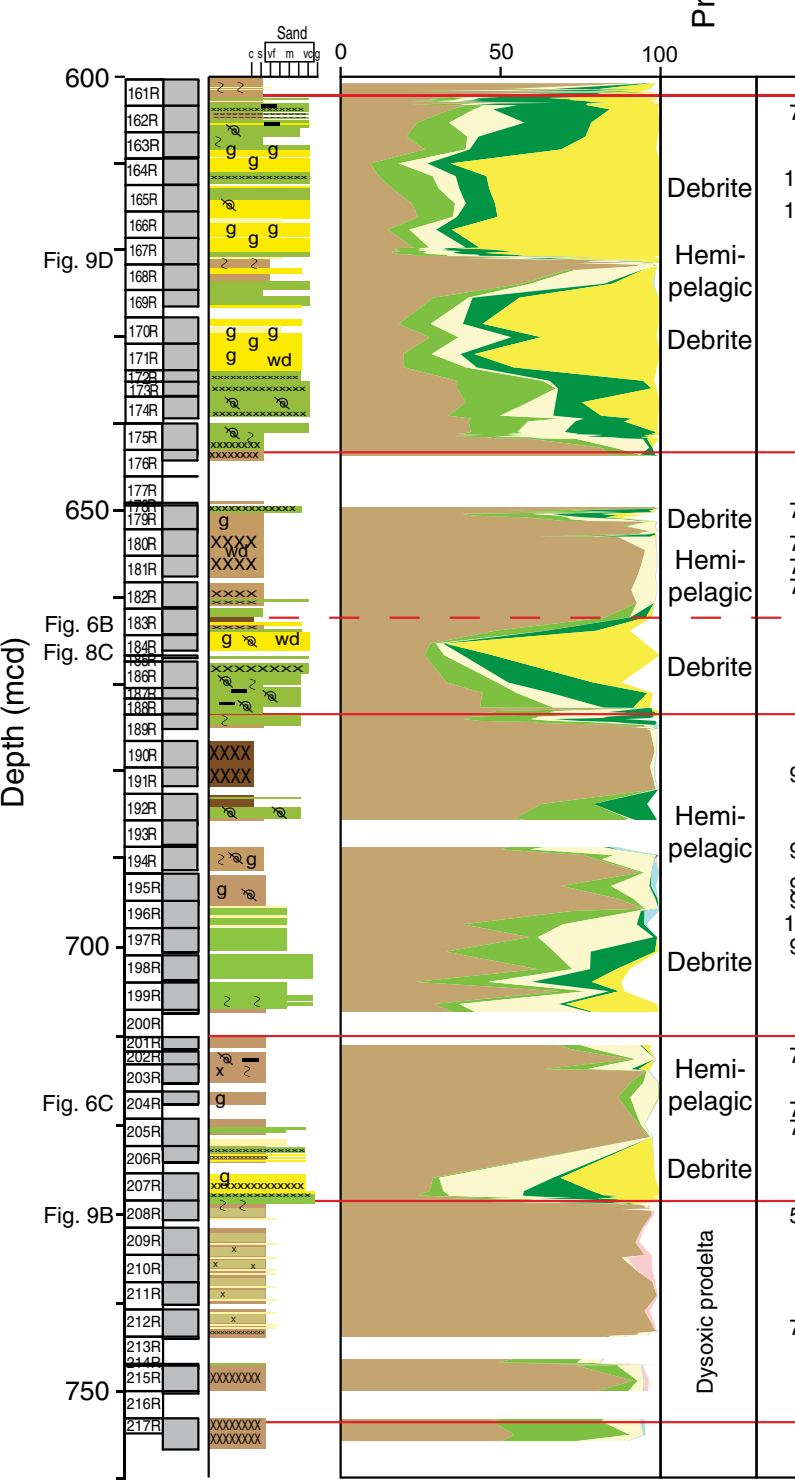

100-110 m

100-110 m

75

$100 \mathrm{~m}$

$100 \mathrm{~m}$

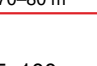

75-100 m

$75-100 \mathrm{~m}$
$75-100 \mathrm{~m}$
$75-100 \mathrm{~m}$

$\stackrel{-75-100 \mathrm{~m}}{-} \frac{75}{75} \mathrm{~m}$

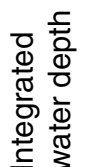
$\begin{array}{llll}0 & 4 & 8 & 12\end{array}$

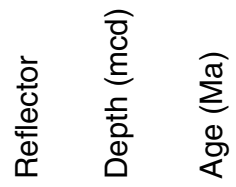

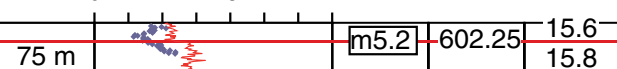

$100 \mathrm{~m}$

$100 \mathrm{~m}$

$75 \mathrm{~m}$
$85 \mathrm{~m}$
$95 \mathrm{~m}$

$100 \mathrm{~m}$

$50-80 \mathrm{~m}$
$90-100 \mathrm{~m}$

$\begin{array}{llll}75 \mathrm{~m} & \\ 85 \mathrm{~m} & 062.37 & \frac{17.7}{17.7} \\ 75 \mathrm{~m}\end{array}$

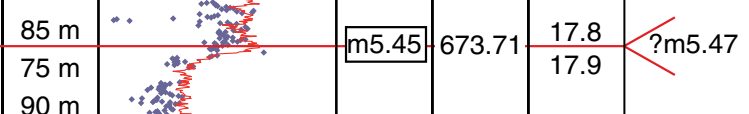

$90 \mathrm{~m}$ 解

$90-100 \mathrm{~m}$
$900 \mathrm{~m}$

$98-180 \mathrm{~m}$

$100-120 \mathrm{~m}$
$90-110 \mathrm{~m}$

$75 \mathrm{~m}$

$90 \mathrm{~m}$

$100 \mathrm{~m}$

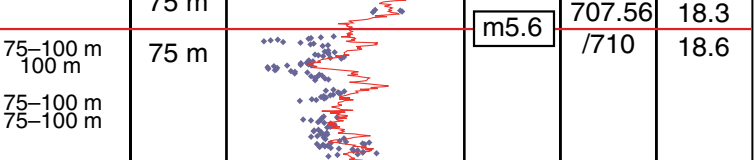

50-100 m

$75 \mathrm{~m}$

\begin{tabular}{l|l|l} 
& & \\
& &
\end{tabular}

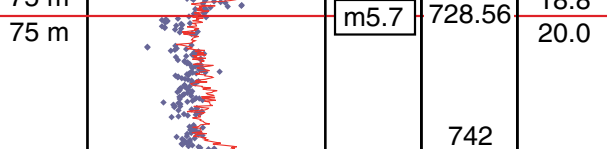

$5-100 \mathrm{~m}$

$50-80 \mathrm{~m}$
$50-100 \mathrm{~m}$
$50-80 \mathrm{~m}$

$75 \mathrm{~m}$

200
TGR $(\mathrm{cps})$ 


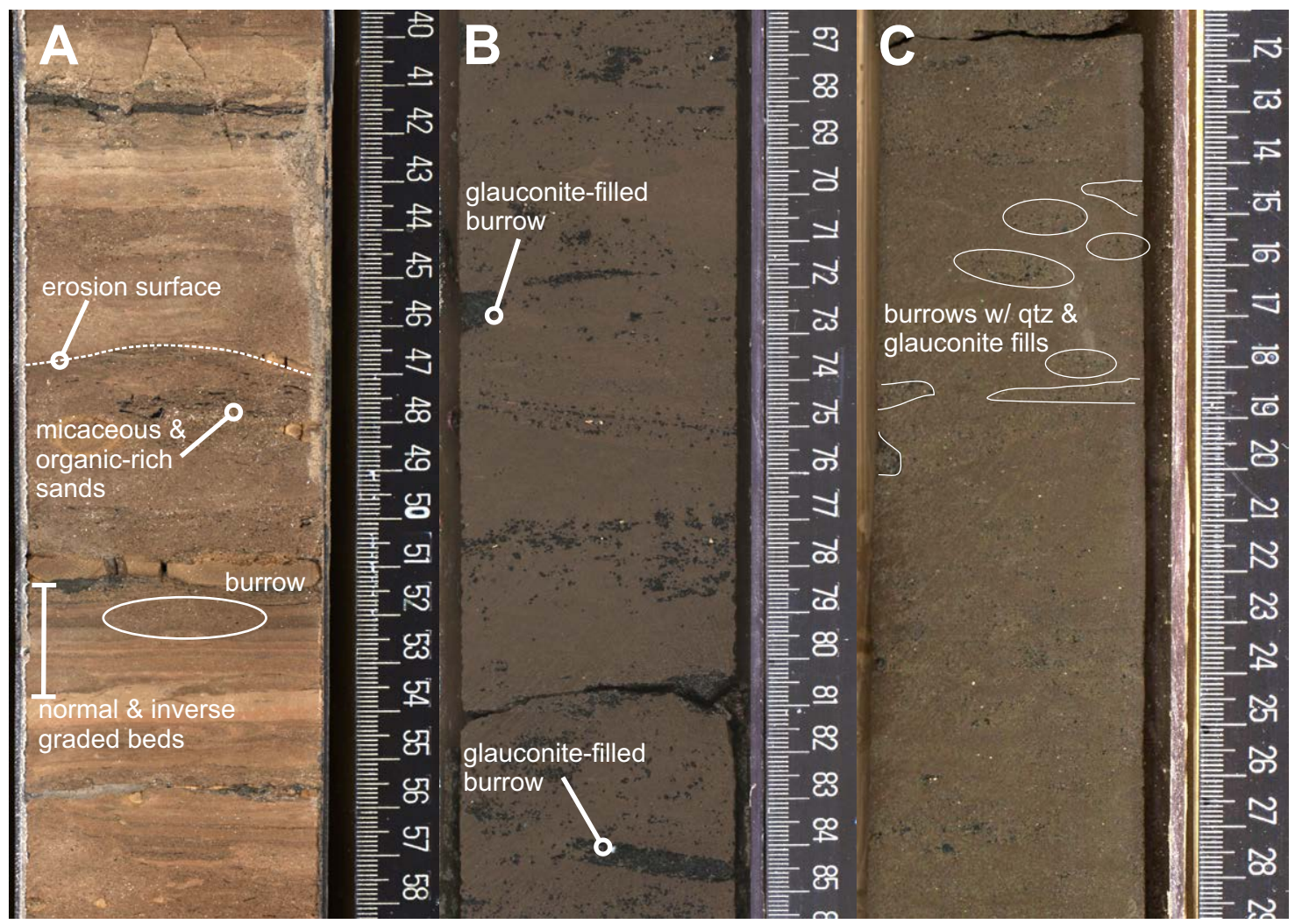

Figure 6. Representative core photos from fine-grained bottomset deposits. Scales are in centimeters. (A) From sequence m5.8 (core 313-28-A-155-1-1), tan-colored thin-bedded succession with alternating stratified and bioturbated intervals (type 1 fine-grained facies). (B-C) Bioturbated clayey silt from sequence $\mathrm{m} 5.45$ (core 313 29-A-183-1-1) with in situ glauconite in burrow fills (B), and bioturbated clayey silt from sequence $\mathrm{m} 5.7$ (core 313-29-A-2041-1) (C), both type 2 fine-grained facies. qtz-quartz.

Type 2 fine-grained facies are found above the m5.7 sequence boundary, where fine-grained units comprise homogenous dark brown clayey silt to silt beds that contain a few percent quartz sand (Figs. 5 and 6). Rare glauconite sand, mica, and lignite are present. Commonly, glauconite is found in equal percentage to the quartz in the same sample. The fine-grained units commonly display a mottled texture suggestive of heavy bioturbation. Thin-walled bivalve shells, shell hash, and benthic foraminifers are commonly present (Fig. 6). Typically, bivalve shells are disarticulated and randomly arranged in the sediments. The fine-grained sediments contain sharp-based normally graded beds with parallel and ripple laminations.

\section{Interpretation}

The abundance of plant debris and mica in type 1 fine-grained units (below the m5.7 sequence boundary) indicates a fluvial source for the sediment The well-laminated silty clays, absence of burrowing fauna, and presence of concretions indicate a quiet depositional environment and an open shelf that experienced repeated periods of dysoxic bottom-water conditions. At times of better oxygenation, the infauna was dominated by horizontally mining deposit-feeding organisms. The gradational upper and lower boundaries and inverse grading of the very fine, parallel- and ripple-laminated sand beds, as well as the millimeter-scale clay-silt lamination in the clay, point to deposition from river flood events (Mulder et al, 2003, Plink-Björklund and Steel, 2004) with fine-scale cyclicity possibly indicating seasonal discharge (e.g., Gugliotta et al., 2016). The coarsening-upward pattern indicates progressive shallowing from lower to upper prodelta environments.

The presence of benthic foraminifers in type 2 fine-grained units (above the m5.7 sequence boundary) shows deposition in an oxygenated marine setting below storm weather wave base. Benthic foraminiferal biofacies analysis (Katz et al., 2013) indicates that most of these units were deposited at paleowater depths of at least $75-100 \mathrm{~m}$. The thin normally graded beds indicate turbidity currents that transported quartz and glauconite sand into the depositional 
environment, although much of the fine-grained sediment was likely deposited from suspension fallout. The presence of rare mica and lignite show minor influence from a riverine source (less than in sequence m5.8). Intense bioturbation implies slow sedimentation rates.

\section{Coarse-Grained Facies}

Coarse-grained lower foreset and bottomset deposits are abundant in cores from Sites M28 and M29 (M28, 500-611.6 mcd; M29, 600-728.56 mcd; Figs. 3-5).

\section{Description}

Typically, the coarse siliciclastic lower foreset and bottomset deposits are either glauconitic quartz sands and gravels or glauconite-dominated sands. Quartz and lithic granules are subrounded to subangular, although the full range of well-rounded to angular granules occurs. Two broad types of coarse clastic deposits are identified: (1) normally graded, moderately sorted, and planar- to cross-stratified (decimeter-scale) medium and coarse sands, which locally form inclined meter-thick bedsets with intercalated clay laminae and burrows (especially the bottom of sequence m5.47, Site 28, cores 117 and 120 527.75-533.59 mcd; Fig. 7 and (2) ungraded, poorly sorted, poorly stratified muddy sands (10\%-30\% silt and clay) with floating granules, articulated thinwalled bivalve shells, and pristine benthic foraminifers (Fig. 8). Overall, the poorly sorted and poorly stratified facies dominates coarse-grained lower foreset and bottomset successions.

\section{Interpretation}

Normally graded and cross-stratified sands and gravels are interpreted as deposits of high-concentration turbidity currents (Fig. 7; Mulder and Alexander, 2001). The inclined meter-thick bedsets with burrows and clay laminae suggest formation and episodic migration of dune-scale bedforms. The cross-bedding indicates a sustained high-energy context where bypassing turbidity currents built dune-scale bedforms (Fig. 7; Amy et al., 2000; Stevenson et al., 2015) on the lower foreset. Locally, there are concentrations of coarse grains that are interpreted as lag deposits recording sediment bypass above erosion surfaces (Stevenson et al., 2015).

Poorly sorted and poorly stratified muddy sands are interpreted as debrites (debris-flow deposits; Mulder and Alexander 2001). A transport mechanism of

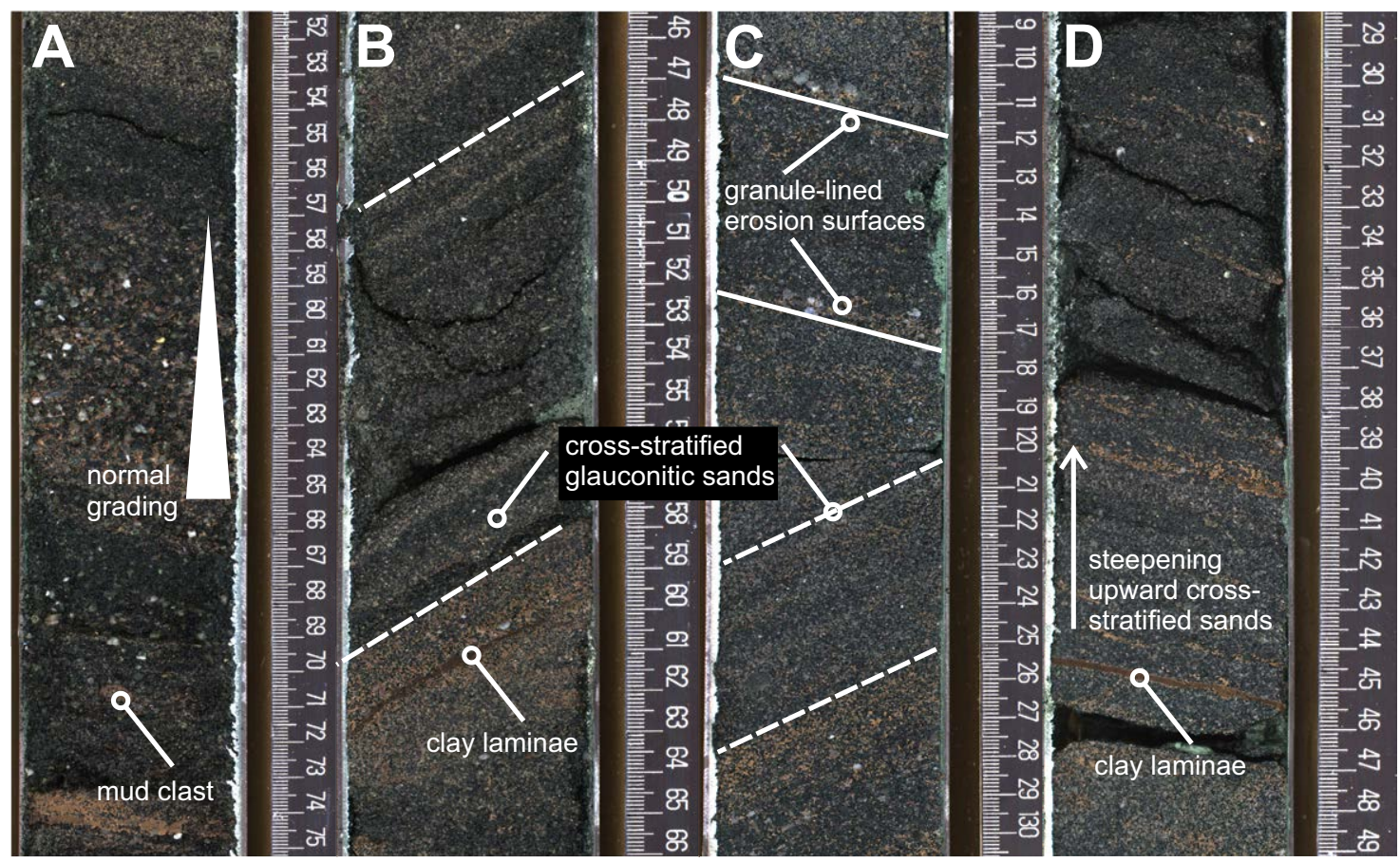

Figure 7. Representative core photos from coarse-grained bottomset deposits intepreted as turbidites. Scales are in centimeters. (A) From sequence m5.45 (core 313-28A-118-2), normal grading in a very coarse to fine glauconite sand bed interpreted as a turbidite. (B) From sequence m5.45 (core 313-28A-118-1), moderately sorted glauconitic medium sand crossbeds. (C) From sequence m5.45 (core 313-28A-119-1), moderately sorted glauconitic medium sand cross-beds. Note the changes in grain size and apparent change in cross-bed dip direction (dashed lines to pick out laminae), interpreted to indicate dune-like bedforms, possibly with different migration directions. (D) From sequence $\mathrm{m} 5.45$ (core 313-28-A-118-2-1) moderately sorted glauconitic medium sand cross-beds. Note apparent steepening-upward trend in dip of cross-stratifcation with clay-rich interlamination indicating episodic migration of a dune-scale bedform. 

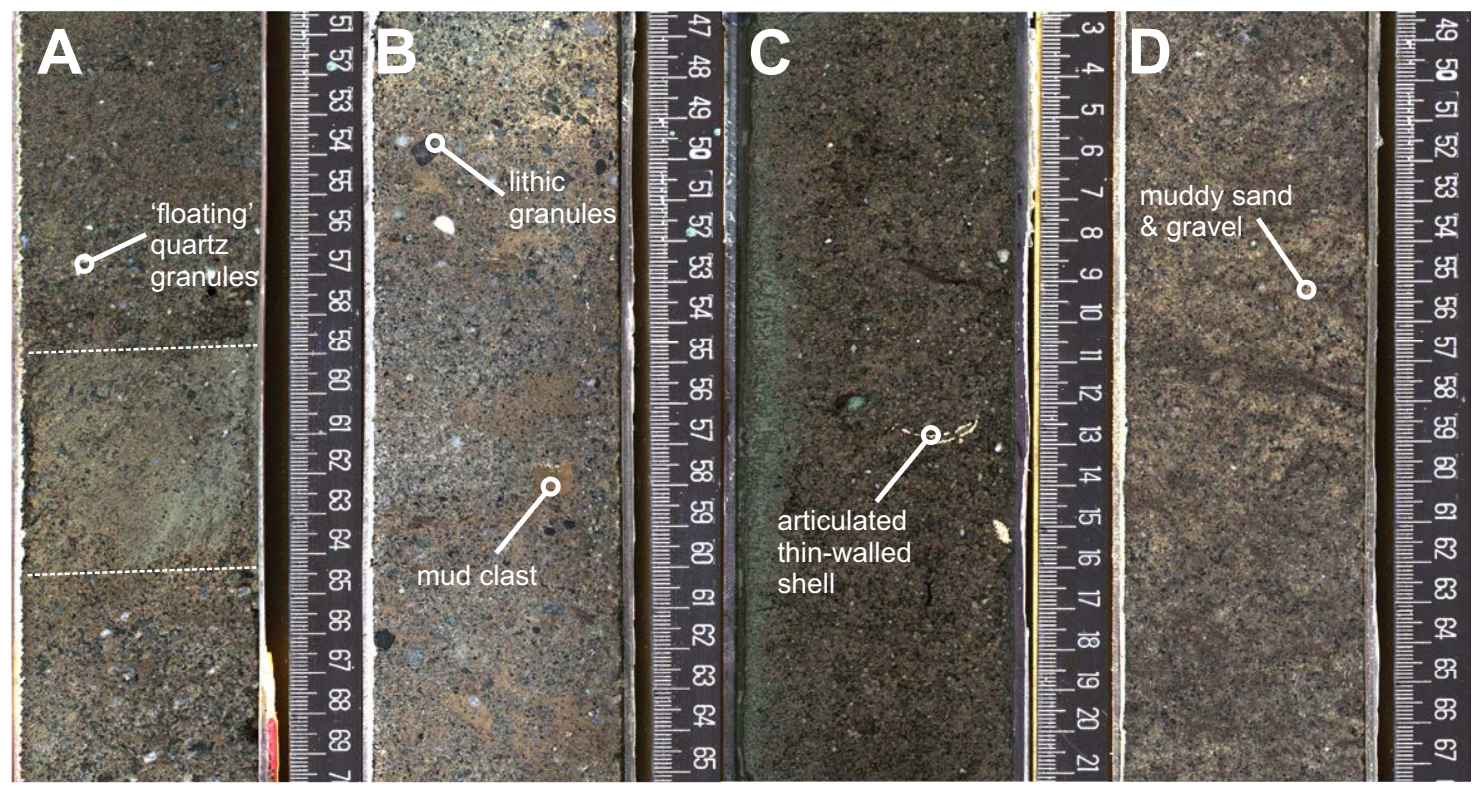

Figure 8. Representative core photos from coarse-grained bottomset deposits interpreted as debrites. Scales are in centimeters. (A) From sequence m5.7 (core 31328-A-136-2-1), stratifed (dotted lines are bed contacts) poorly sorted muddy sand and gravel grains supported by (floating in) a finer grained matrix. (B) From sequence m5.6 (core 313-28-A-129-2-1), unsorted muddy sand and gravel. Note intraformational mud clasts and extrabasinal (C) From range from angular to rounded. (C) From sequence m5.45 (core 313-29-A184-2-1), poorly sorted muddy sand with an articulated thin-walled shell. (D) From sequence $\mathrm{m} 5.7$ (core 313-28-A-145-1-1), poorly sorted muddy sand, with a high mud content. Scales are in centimeters.

cohesive flows with little internal turbulence is supported by the thin-walled articulated shells and pristine benthic foraminifera dispersed in the muddy sands (Fig. 8). Rounded intraformational (bioturbated) mud clasts and the high proportion of glauconite sand grains record upslope erosion and substrate entrainment. The interpreted environments of deposition of the coarse-grained bottomset deposits are discussed below.

\section{DTRATIGRAPHY OF BOTTOMSETS}

The lithofacies successions are described within individual sequences focusing on Site M29 (Fig. 5), then compared to Site M28 (Fig. 4), which were both strategically sited to sample multiple bottomset successions.

\section{Site M29}

The m5.7 sequence (728.56-707.56/710 mcd at Site M29) comprises coarse sand with floating pebbles at the base, overlain by fine-grained sediments (Fig. 5). The basal m5.7 sequence boundary at Site M29 (728.56 mcd; 20.0 18.8 Ma; Fig. 9) is marked by an abrupt change from silty clays and clayey silts below (type 1 fine-grained facies) to glauconitic coarse and medium sands with angular clasts of clayey silts above (Figs. 5 and 9). The contact is sharp and heavily disturbed through bioturbation, including large glauconitic coarse and medium sand-filled branching burrows (Thalassinoides) that extend downward tens of centimeters (as much as $0.49 \mathrm{~m}$ below the contact; Fig. 9). The overlying succession (728.56-725.4 mcd) comprises $\sim 3 \mathrm{~m}$ of moderately to poorly sorted medium sands that are a mix of glauconite and quartz, with rare granules. These are interpreted as mass-flow deposits, largely debrites, with rare thin turbidites as evidenced by thin $(2-10 \mathrm{~cm})$ glauconite quartz sands. The sands become muddy sands above $725.4 \mathrm{mcd}$ and become increasingly silty to $717.7 \mathrm{mcd}$, above which they are predominantly silts. The exact nature of the contact between sands and silts is obscured by drilling disturbance. The overlying $\sim 10 \mathrm{~m}$ comprise sandy silts and silts with subhorizontal burrows, with rare glauconitic sand beds. These are interpreted as hemipelagic deposits intercalated with silt-prone low-concentration turbidites. The location of the top of the m5.7 sequence is uncertain due to a coring gap $(707.56-710.0 \mathrm{mcd})$.

Sequence m5.6 (707.56/710.0-673.71 mcd at Site M29) comprises coarse glauconite and quartz sand at the base with silts at the top (Fig. 5), repeating the pattern of the underlying $\mathrm{m} 5.7$ sequence. The basal $\mathrm{m} 5.6$ sequence boundary at Site M29 (18.6-18.3 Ma) is placed in a coring gap (707.56-710.0 mcd) and is marked by a change from bioturbated silts below to poorly sorted, slightly glauconitic quartz sands above. Glauconitic sand-filled burrows in the underlying silts indicate the presence of deep (at least $1.17 \mathrm{~m}$ ) bioturbation. Interbedded silty sand and medium sand extend to $\sim 682.7 \mathrm{mcd}$. The sediment from the m5.6 sequence boundary to 695.65 mcd comprises poorly sorted medium and coarse glauconitic quartz sands that fine upward to silty fine sands (695.65- 


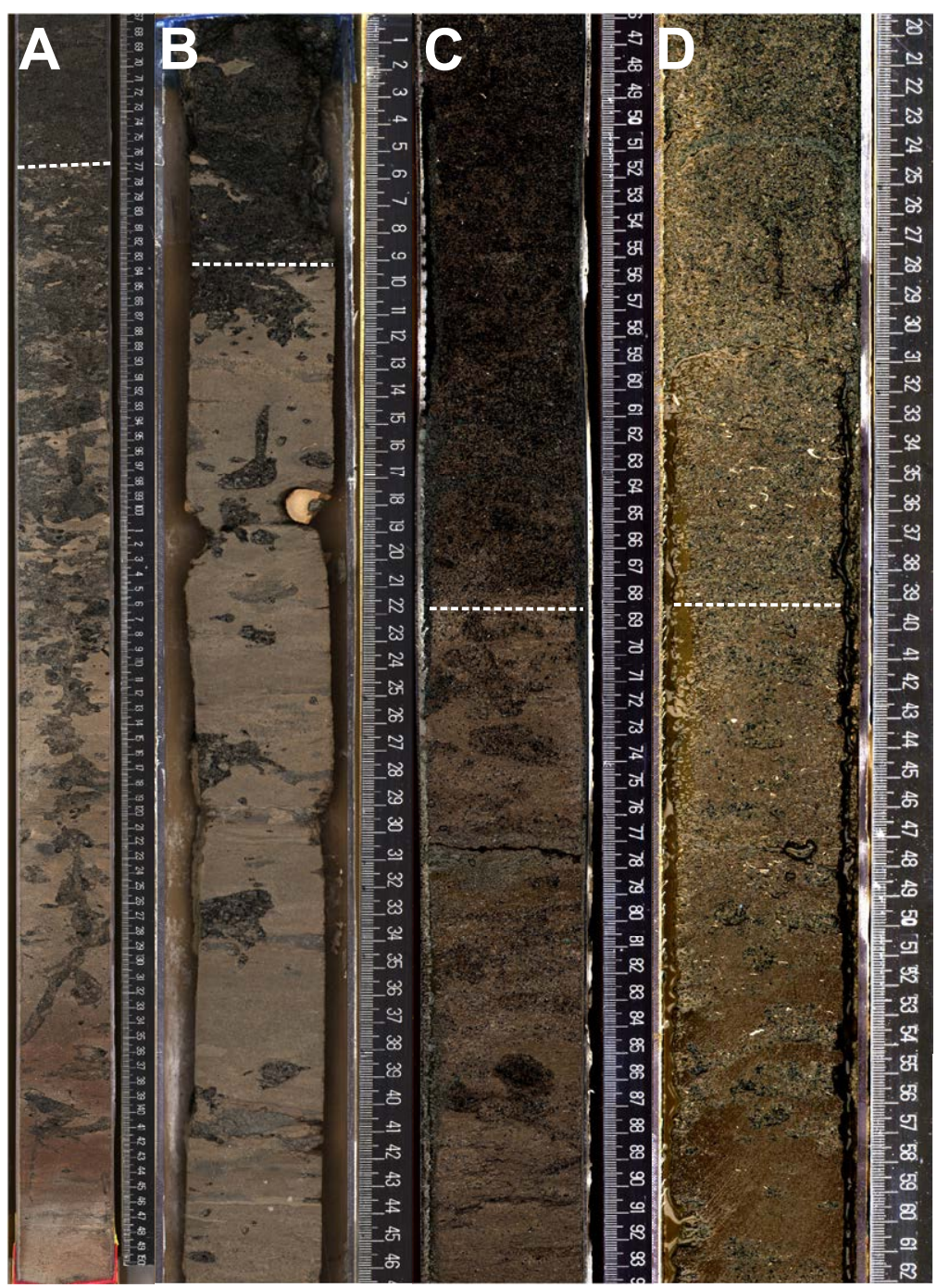

$692.7 \mathrm{mcd}$ ), with an increase in glauconite. These are interpreted as debrites with rare thin turbidites. The overlying $10 \mathrm{~m}(682.7-673.71 \mathrm{mcd})$ succession comprises silts with common benthic foraminifers and glauconite-filled burrows deposited in a low-energy environment.

The $\mathrm{m} 5.47$ sequence boundary was reported by Miller et al. (2013b) in this succession at 695.65 or $683.17 \mathrm{mcd}$. There is no clear change in facies at either depth, and overall the interval fines upwards to clayey silts and silty clays
Figure 9. Representative core photos from basal contacts (dashed lines) of coarse-grained bottomset deposits. Scales are in centimeters. (A) Base of sequence m5.7 (core 313-28-A-152-1-1). The overlying medium sand $(65-76 \mathrm{~cm})$ increases in the proportion of glauconite downhole $(2 \%$ $20 \%$ ) to an intensely bioturbated contact (at $76 \mathrm{~cm}$ ) with silty clay. Burrows in clay are filled with glauconite sand, including a large vertical burrow with sharp scalloped margins and multiple branches identified as Thalassinoides and Ophiomorpha. (B) Base of sequence $\mathrm{m} 5.7$ (core 31329-A-208-1-1), showing a sharp contact (at $9 \mathrm{~cm}$ ) between dark green-brown glauconite sandstone above and pale brown clayey silt below. Glauconite sand-filled Thalassinoides burrows are in the underlying clayey silt. This surface is interpreted as an unconformity. (C) Candidate m5.4 sequence boundary (core 313-28-A-113-1-1, 49-91 cm). Poorly sorted fine glauconite sand $(40 \%)$ bounded below by a sharp surface $(a t 68 \mathrm{~cm}$ ) above a claystone with burrows filled with glauconite sand from above $(68-88 \mathrm{~cm})$. Firmground required some time to be formed before sand deposition. (D) Candidate sequence boundary at Site 29 (core 313-29-A-167-2-1, 34-39 cm) above the m5. 3 sequence boundary, marked by a sharp contact between bioturbated silt below and glauconitic fine sand with large angular clasts of the bioturbated silt above.

$\leftarrow$

with thin-walled shells. Reexamination of the seismic profiles suggests that the $\mathrm{m} 5.47$ sequence boundary merges with the $\mathrm{m} 5.45$ sequence boundary, which is best placed at $673.71 \mathrm{mcd}$, suggesting that the entire interval from $707.56 / 710$ to $673.71 \mathrm{mcd}$ is sequence $\mathrm{m} 5.6$ (Fig. 5).

The m5.45 sequence (673.71-662.37 mcd at Site M29) consists of coarsening-upward fine to medium and coarse sand and overlying silty clay (Fig. 5) once again repeating the pattern seen in underlying sequences. The m5.45 sequence boundary at Site M29 (17.9-17.8 Ma) is marked by an abrupt and intensely bioturbated surface at $673.71 \mathrm{mcd}$ separating silty clay below from glauconitic quartz sand above (Fig. 5). Burrows filled with glauconite sand are found $0.38 \mathrm{~m}$ below the contact. The overlying $~ 11-\mathrm{m}$-thick sands (to 662.37 $\mathrm{mcd}$ ) are highly glauconitic at the base, but there is an overall increase in medium and coarser quartz sand upsection (Fig. 5). No stratification is observed and the sands are poorly sorted and include extrabasinal pebbles and thinwalled articulated shells. These are interpreted as debrites. There is an abrupt upsection decrease in grain size from poorly sorted pebbly silts to silty clay at $662.37 \mathrm{mcd}$ (Fig. 5) where the basal m5.4 sequence boundary was placed by Miller et al. (2013b). The silt succession (662.37 to $649.16 \mathrm{~m}$ or higher; with a $\sim 5 \mathrm{~m}$ coring gap from 649.16 to $644.28 \mathrm{mcd}$ ) is bioturbated and varies from silty clay to sandy silt, with scattered thin-walled shells and benthic foraminifers. Rare glauconitic sands are centimeters thick and weakly graded. These are hemipelagic deposits, with rare thin quartz and glauconite quartz sands interpreted as turbidites. The section from 662.37 to $643.19 \mathrm{mcd}$ was originally assigned to sequence m5.4 by Miller et al. (2013b). However, on the seismic line, reflector $\mathrm{m} 5.4$ merges with reflector $\mathrm{m} 5.3$ and sequence $\mathrm{m} 5.4$ pinches out between Site M28 and M29 (Fig. 3). Basinward of the pinchout, sequence m5.4 was interpreted by Miller et al. (2013b) to reappear. An equally plausible interpretation of the seismic data is that this interval is the upper part of sequence $\mathrm{m} 5.45$. The facies successions of m5.7 and m5.6 show coarse sand overlain by bioturbated silts. Therefore, assigning the section $662.37-643.19 \mathrm{mcd}$ to sequence $\mathrm{m} 5.45$ would follow this pattern of lower debrite-prone sands overlain by hemipelagic and turbiditic silts. 
Sequence m5.3 (643.19-602.25 mcd at Site M29) consists of two thick packages of coarse sand separated by a thin bioturbated clayey siltstone (Fig. 5). The basal m5.3 sequence boundary $(643.19 \mathrm{mcd})$ is a sharp contact between underlying bioturbated silt and overlying glauconitic fine sand with large angular clasts of the bioturbated silt. The contact is bioturbated, with Thalassinoides burrows filled with glauconite sand down to $0.18 \mathrm{~m}$ below the contact. The lower section is stratified with alternations of medium-grained glauconite sands and poorly sorted muddy glauconite sands with thin-walled shell debris and dispersed benthic foraminifers and granules. Overall, the $20 \mathrm{~m}$ sand-prone succession coarsens upward, with an increasing component of poorly sorted structureless fine and medium quartz sand (Fig. 5), which contains dispersed extrabasinal rounded to subangular granules and small pebbles, and articulated shells. The ratio of quartz sand to glauconite sand increases upsection to a 0.56 -m-thick intensely bioturbated transition from a poorly sorted sandstone to a 3-m-thick bioturbated clayey siltstone with a large quantity of fragmented thin-walled shells (core 313-M29-168-2) and several thin (3-6-cm-thick) sharp-based and weakly graded medium quartz sands. The clayey silt is abruptly overlain by coarse to medium glauconitic sand, with Thalassinoides burrows filled with coarse glauconite sand $1 \mathrm{~m}$ below the contact $(620.58 \mathrm{mcd}$; Fig. 9). The overlying $\sim 20-\mathrm{m}$-thick sand (from 620.58 to $602.25 \mathrm{mcd}$ ) dominantly comprises moderately to poorly sorted medium to coarse quartz sand with rounded to subangular granules (Fig. 5). The component of muddy glauconite sand increases upsection, with a fining-upwards and increasingly stratified bioturbated succession of muddy sand and sandy mud.

The two sand packages in sequence m5.3 are $\sim 20 \mathrm{~m}$ thick with deeply burrowed basal surfaces, and dominated by debrites, with the lower one coarsening upward and increasing in the proportion of quartz sand, and the upper package fining upward and increasing in muddy glauconitic sand. A 3-m-thick hemipelagic interval with rare turbidites separates the sand packages. The two sand packages might represent two parasequences within a single LST. However, the intervening hemipelagic interval suggests a significant shutdown in sediment supply, and the comparable nature of the basal contact to the upper sand with the $\mathrm{m} 5.7, \mathrm{~m} 5.6, \mathrm{~m} 5.45$, and $\mathrm{m} 5.3$ sequence boundaries points to the presence of an additional sequence boundary. If there are two lowstand sequences, then the bioturbated clayey silt contains the deepwater equivalent to a maximum flooding surface and combined TST and HST, and one LST has been removed through erosion upsection.

In summary, at Site M29 there is a clear stratigraphic packaging in the bottomset stratigraphy, with sharp-based coarse-grained units above the m5.7, m5.6, m5.45, and m5.3 sequence boundaries and the candidate "intra-m5.3" sequence boundary (Fig. 9), which pass into overlying packages of hemipelagic muds and bioturbated silts. The coarse-grained packages are several meters thick $(\sim 10-20 \mathrm{~m})$ and comprise debrites with rare turbidites. The contacts are sharp and locally marked by large glauconitic sand-filled branching burrows (Thalassinoides) that extend tens of centimeters below erosion surfaces.

\section{Site M28}

The same stratigraphic interval recovered at Site M29 was also recovered $9 \mathrm{~km}$ updip at Site M28, allowing a comparison of bottomset stratigraphy (Fig. 4). Based on seismic cross-sections and chronostratigraphic dating, the $\mathrm{m} 5.7, \mathrm{~m} 5.6, \mathrm{~m} 5.47$, and $\mathrm{m} 5.45$ sequences are in lower foreset to bottomset positions at Site 28, whereas sequence m5.3 is in a rollover position (Fig. 3). Sequence $\mathrm{m} 5.4$ is present at Site M28 but is not confidently resolved at Site M29, and sequence $\mathrm{m} 5.47$ appears to be missing at M29. At Site M28, sequences $\mathrm{m} 5.7$ ( $44.1 \mathrm{~m}$ thick), m5.6 ( $22 \mathrm{~m}$ thick), $\mathrm{m5} .47$ ( $12 \mathrm{~m}$ thick) and $\mathrm{m} 5.45$ (21.3 m thick) are sand prone and amalgamated, with no fine-grained intervals preserved apart from a rare thin (0.2-m-thick) and bioturbated silty clay and clay unit at the top of sequence m5.47, and the upper part of m5.45 (Fig. 4). The basal contact of sequence m5.7 is an abrupt contact between bioturbated silty clay below and medium glauconite sand above (Fig. 4). The contact is heavily disturbed by bioturbation, with poorly sorted medium to coarse glauconite sand filling Thalassinoides burrows, which are identified down to $1.12 \mathrm{~m}$ below the contact (Fig. 9). The overlying sands are quartz rich and coarsen upwards from dominantly fine sand to dominantly medium sand with dispersed subrounded to subangular quartz granules and small pebbles over the lower $\sim 20 \mathrm{~m}$ (Fig. 8), but there is little stratification. Around the m5.6 sequence boundary, there is an influx of glauconite in the poorly sorted sands (Fig. 4), but the succession remains sand rich, poorly sorted, and weakly stratified. There is a marked increase in the amount of glauconite sand at the m5.47 sequence boundary (Fig. 4), although the facies above are the same as the m5.6 sequence. The base of sequence m5.45 is marked by very coarse sand and is highly disturbed by large burrows. The grain size and ratio of glauconite to quartz in the overlying 10-m-thick succession is consistent in sequence m5.45; however, there is a marked increase in stratification with changing grain size and sorting, and several normally graded beds (Figs. 4 and 7). Some units show clear subparalle centimeter-thick sand laminations that steepen upwards, with rare intercalated clay laminae interpreted to be turbidites, and episodically migrating dunes (Fig. 7). The upper part returns to a succession of poorly sorted glauconitic sands, which transitions through a bioturbated glauconitic sandy silt to a clay (Fig. 4). Another sharp-based sand forms an 8-m-thick fining-upward package of stratified sands with a bioturbated contact (core 313-M28-113-1, $68 \mathrm{~cm} ; 519.7$ mcd; Fig. 9) that is an alternative base of sequence m5.4

\section{DISCUSSION}

\section{Environments of Deposition of the Bottomsets}

The one-dimensional (1-D) corehole data and 2-D seismic data permit the interpretation of the depositional environments of coarse-grained bottomset deposits of the intrashelf clinothems (Fig. 10). At Site M28, the presence of episodically migrating dunes and clast-rich horizons in sequence m5.45 support the presence of a sediment bypass-dominated zone (sensu Stevenson 

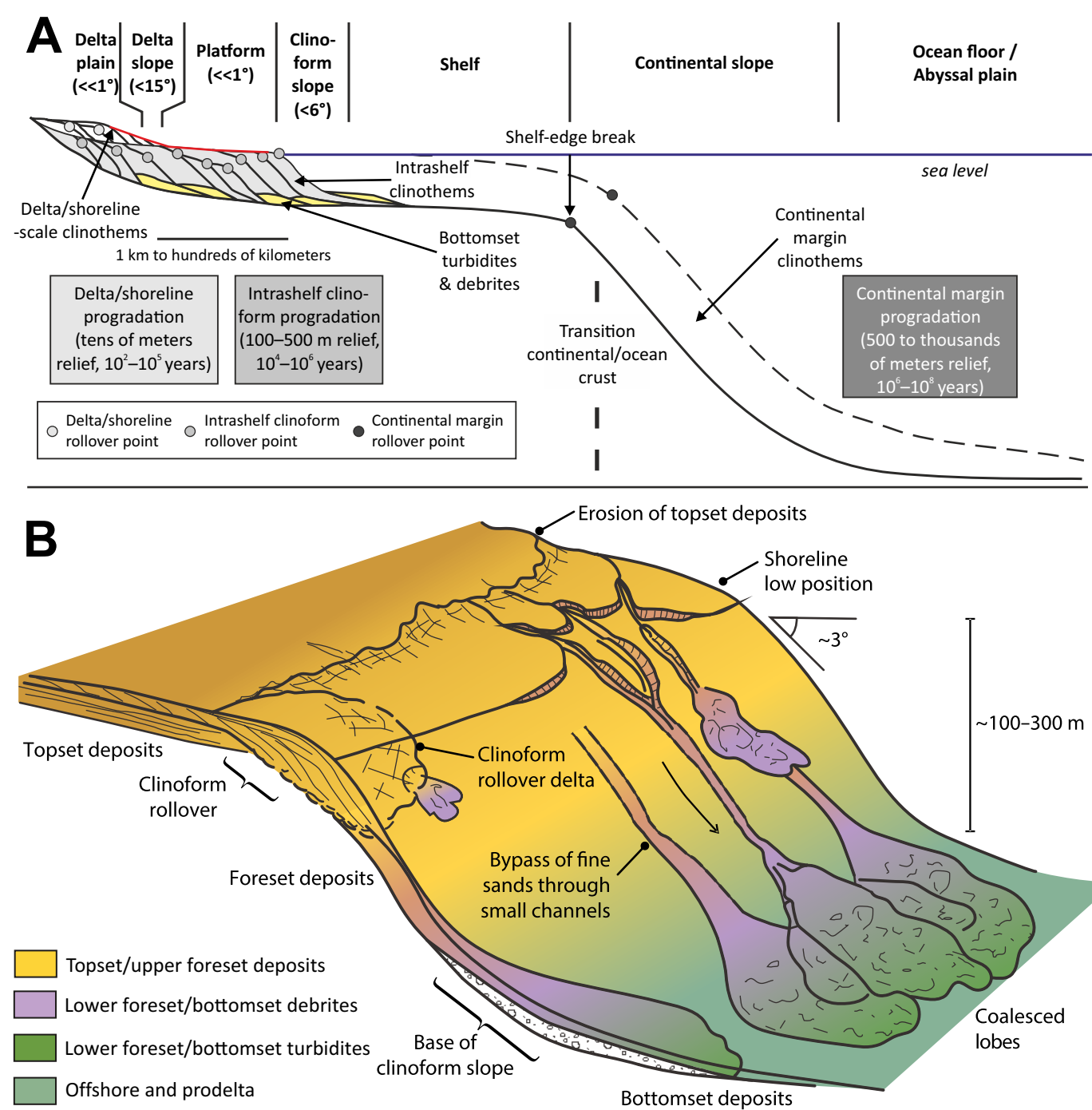

Offshore and prodelta
Erosion of topset deposits

Shoreline

low positio $\sim 100-300 \mathrm{~m}$ et al., 2015) and possible submarine channel fills. This, together with the amalgamation of sand-rich units in lower foreset and bottomset deposits (Figs. 4 and 11), suggests higher amounts of erosion in more proximal positions. The sharp bases to packages at Site M29 and deep bioturbation also support erosion. However, the bottomset position, the 10-20-m-thick coarsening- then fining-upward or fining-upward sand-prone packages (Figs. 4 and 5), and the seismic architecture (Fig. 3) in all sequences point to relatively unconfined de- posits. Therefore, the sharp-based packages are interpreted as stacked deepwater lobe deposits dominated by debrites (Fig. 10). Each coarse-grained package at Site M29 has its own thickness, ratio of glauconite to quartz sand, and grain-size distribution, which could suggest compensational stacking of lobe deposits (e.g., Prélat et al., 2009). Several studies have shown that compensational stacking of basin-floor elements can occur across a range of scales (e.g., Deptuck et al., 2008; Prélat et al., 2009; van der Merwe et al., 2014). 
Figure 11. Chronostratigraphic correlation between Sites M28 and M29 that illus trates the updip amalgamation of lowstand systems tract deposits (Site M28) and the better downdip completeness (Site (Site M29). Red lines represent sequence boundaries (dashed where placement is bol explanation. mcd-meters composite bol explat

Site 313-28

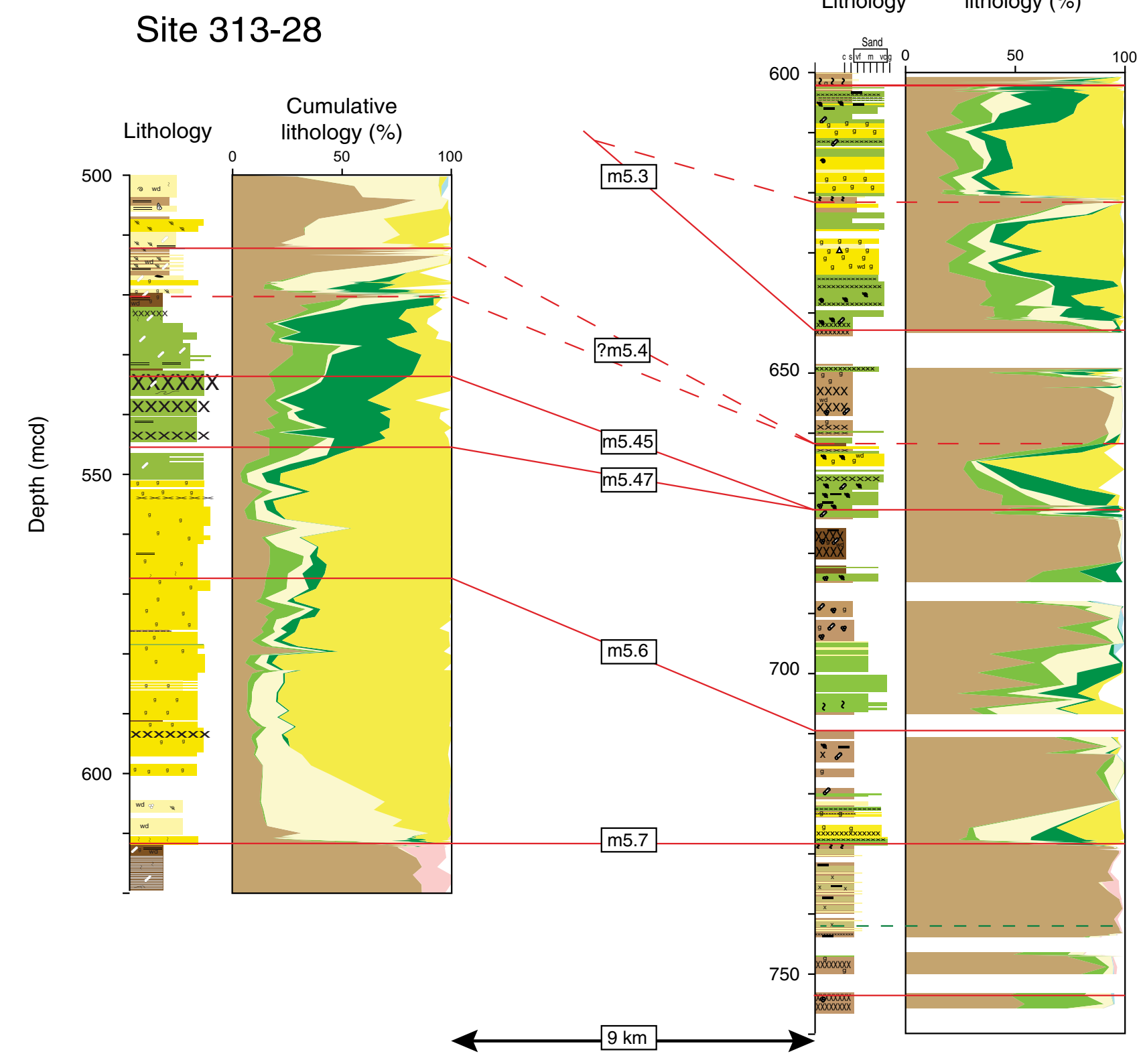


It is striking that coreholes at both Sites M28 and M29, which are $9 \mathrm{~km}$ apart in a dip direction, intersected the same sharp-based coarse-grained deposits in all sequences, apart from m5.47 (Fig. 11). This can be explained in two ways. The corehole transect may have intersected multiple channels and/or gullies along the foreset slope, indicating the formation of an apron system (e.g., Nelson et al., 1999) or coalesced lobes at the foreset to bottomset positions of successive intrashelf clinothems (Fig. 10). An alternative is that the wells intersected a long-term sediment transport conduit (Site M28) and coeval stacked bottomset units with weak compensational stacking (Site M29). However, 2-D reflection seismic lines that are oriented along strike to the foreset slope (Monteverde et al., 2008) do not image any major conduits at the m5.7-m5.3 stratigraphic interval.

The 2-D reflection seismic data do not resolve the nature of the updip sediment supply system. Mountain et al. (2010) reported two types of coarsegrained facies deposited in clinothem rollover positions: (1) quartz-rich clean sandstones, interpreted as wave-dominated shoreface deposits, and (2) poorly sorted glauconitic sand, interpreted as river-dominated clinoform rollover deposits with recycled glauconite. The glauconite- and quartz-rich character of the bottomset sands and the chronostratigraphic control (Browning et al., 2013) support a correlation with the river-dominated rollover systems (poorly sorted glauconitic sand). The large number of lithic granules and the high amount of glauconite grains suggest that bottomset sediments were sourced through reworking of older clinoform topset and rollover deposits (Fig. 10). The subangular nature of the quartz and lithic sand grains point to a limited residence time in the fluvial transport system from hinterland erosion to bottomset deposition. Therefore, we favor a reconstruction with the presence of a distributive fluvial system on the topsets at times of high sediment supply to the bottomsets, and the presence of multiple gullies and channels cutting the foresets (Fig. 10). In the fine-grained bottomset deposits, the deposits may have been sourced from river flood events, i.e., hyperpycnal flows. However, the relative dominance of coarse-grained debrites suggests that the majority of flows were not hyperpycnal in origin, and were more likely sourced from collapse of coeval river-dominated systems at the intrashelf clinoform rollover (Piper and Normark, 2009; Talling et al., 2013; Fig. 10). This study demonstrates that large amounts of sediment gravity-flow deposits can accumulate in relatively shallow $\left(\sim 100-200-\mathrm{m}\right.$-deep) and low-gradient $\left(\sim 1^{\circ}-4^{\circ}\right)$ clinothems that prograded across a continental shelf (Fig. 10).

Global mapping of present-day continental shelves indicates the worldwide mean $(258 \mathrm{~m})$ and median $(160 \mathrm{~m})$ water depths of the continental shelfedge break (Paris et al., 2016). This high present-day accommodation state is due to flooding (global mean rise of $127 \mathrm{~m}$; Peltier and Fairbanks, 2006). This suggests that intrashelf clinothems of comparable scale could form today given sufficient sediment supply on many continental shelves, as they do on the modern Amazon shelf (Nittrouer et al., 1996). We suggest that the development of intrashelf clinoforms with bottomsets comprising extensive sediment gravity-flow deposits is likely widespread through geological time (e.g., Anell et al., 2014; Patruno et al., 2015; Pellegrini et al., 2017; Fig. 10).

\section{Do Coarse-Grained Bottomset Deposits Represent Lowstand Systems Tracts?}

Miller et al. (2013a, 2013b) described the anatomy of a Miocene depositional sequence on the New Jersey margin, and interpreted the presence of LST deposits in bottomset positions based on a seismically picked sequence boundaries and stratal terminations of seismic reflections (Fig. 3). Here, we consider the sedimentological evidence to support this sequence stratigraphic interpretation of the lower foreset and bottomset succession (Fig. 12). Commonly, the sharp-based debrite and turbidite bottomset packages have deeply burrowed basal surfaces (Fig. 9). The macrofauna that extend into fine-grained units below formed unlined burrow networks. These surfaces are interpreted as deepwater firmgrounds (e.g., Savrda et al., 2001), and indicate the development of an erosional hiatus prior to influx and deposition of coarse-grained sands (Hubbard and Schultz, 2008; Dasgupta and Buatois, 2012; Stevenson et al., 2015). Locally, if the grain size of the burrow fill is coarser than the overlying sands, it suggests a period of sediment bypass with coarse grains being captured and infilling the burrow network (Stevenson et al., 2015). The presence of erosional hiatuses at the base of debritic and turbiditic packages supports the seismically based interpretation that they represent the LST of depositional sequences bounded by an underlying sequence boundary (Fig. 12). The gradational upsection fining and thinning of beds, typically $9-10 \mathrm{~m}$ above the base (Fig. 12), suggest a waning sediment supply that might be a

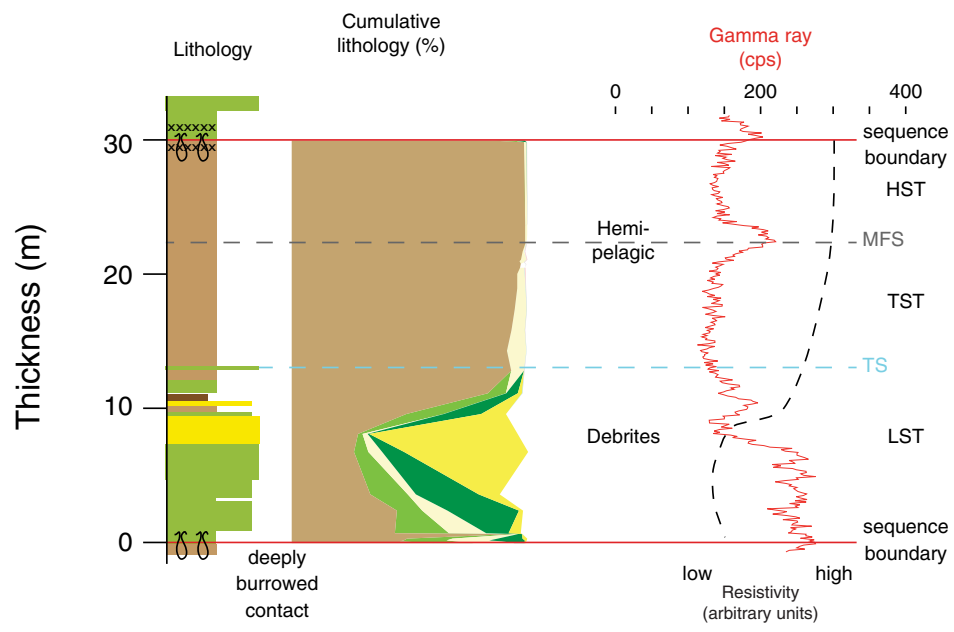

Figure 12. Idealized bottomset succession from the Miocene clinothems, based on sequence m5.45 at Site M29. Note the impact of the high glauconite content on the trace of the gamma ray logs (in cps, counts per second), which obscures the lithological pick of the sequence boundary (red line) (Inwood et al., 2013). See Figure 4 for color and symbol explanation. HST, TST, LST-highstand, transgressive, and lowstand systems tract, respectively; MFS-maximum flooding surface; TS-transgressive surface. 
response to marine transgression and/or a decrease in the rate of sediment supply from the hinterland. The overlying successions (Fig. 12) are interpreted to represent the TSTs and HSTs, and include the deepwater equivalent of the maximum flooding surface (MFS) (Figs. 4, 5, 12). The exact position of the MFS might coincide with the highest gamma-ray spike (Fig. 12). Alternatively, the MFS might have formed during the most extreme coarse sediment starvation and the formation of the deepwater firmground, and was subsequently eroded and merged with the sequence boundary at the base of the overlying coarse-grained unit, as demonstrated by the amalgamation of sequences at Site M28. There are many allogenic and autogenic factors that may have controlled the packaging in the bottomsets. However, the stratigraphic organization of the bottomset deposits, and the coarse-grained immature extrabasina and reworked glauconitic detritus, suggest that the bottomset sedimentation patterns were driven by a combination of relative sea-level cycles and changes in the rate of sediment supply. In summary, the seismic stratigraphic contex and sedimentology of coarse-grained bottomset deposits of the New Jersey intrashelf clinothems (Fig. 12) are consistent with the interpretation of these deposits as forming the LST.

\section{Why Are Bottomsets Dominated by Debrites?}

A striking aspect of the coarse-grained components of lower foreset and bottomset deposits is the high proportion of debrites. Mass flows can undergo transformations during translation by incorporating sediment through erosion, disaggregation of the failed mass, and entraining ambient fluid (water), and transform from slides through slumps and debris flows to become fully turbulent (e.g., Fisher, 1983; Locat and Lee, 2005; Strachan, 2008; Omosanya and Alves, 2013). Therefore, debrites have been viewed as indicators of a proxima setting and are the product of en masse deposition of cohesive flows (e.g., Talling et al., 2012). In contrast, hybrid event beds, which comprise a lower tur bidite and upper "linked" debrite, have been widely identified in distal deepwater settings (e.g., Haughton et al., 2009; Hodgson, 2009; Talling et al., 2013). No hybrid event beds have been identified in the cores analyzed in this study. Furthermore, the presence of articulated thin-walled shells and pristine benthic foraminifers suggests that the flows were cohesive along their length, and did not undergo a longitudinal transformation from cohesive to fully turbulent to cohesive flow rheology prior to deposition as interpreted in other systems (e.g., Fisher, 1983; Talling, 2013). Bottomset deposits from exhumed clinothems of comparable scale and with a physical stratigraphic connection from topset to bottomset positions are usually dominated by turbidites (e.g., Wild et al., 2009 Grundvåg et al., 2014). Therefore, the propensity of debrites in the New Jersey bottomsets is interpreted to be due to the relatively short transport distance from collapse around the likely clinothem rollover source area $(<10 \mathrm{~km})$, which inhibited entrainment of water and retarded transformation to fully fluidal flows (Fig. 10). The evidence for sediment bypass in the bottomset deposits, including erosion surfaces, dune-scale bedforms, and coarse-grained lags (Stevenson et al., 2015), suggests that more turbidite-prone strata will be found in bottom- set deposits basinward of Site M29. In other systems of comparable scale, a higher proportion of turbidites closer to the foreset area might be due to a more direct river influence and the generation of hyperpycnal flows (e.g., Petter and Steel, 2006; Grundvåg et al., 2014).

\section{CONCLUSIONS}

Lower foreset and bottomset deposits were intersected in multiple successive intrashelf clinothems sequences of Miocene age from offshore New Jersey in coreholes drilled during IODP Expedition 313. Up to five depositional sequences in the most basinward research corehole at Site M29 follow a similar motif. Above a sharp and deeply bioturbated basal surface, a coarse-grained sand unit ( 10-20 m thick) composed of reworked glauconite and quartz grains overall fines and thins upwards into bioturbated silts. Stratigraphically, this pattern is interpreted as the expression of a LST in a lower foreset to bottomse position of intrashelf clinothems. The sharp base is the sequence boundary, with deep burrows filled with coarse sands representing hiatus and firmground formation accompanied by erosion and sediment bypass. Overlying stratigraphic grain-size trends and changes in the ratio of glauconite to quartz are interpreted to reflect autogenic controls, and suggest compensational stacking of debritic lobes forming lobe complexes. The overall fining and thinning upward are interpreted as a response to marine transgression and/or a decrease in the rate of sediment supply from the hinterland. These successions are interpreted to represent the combined TST and HST, and include the deepwate equivalent of the MFS. Updip at Site M28, the multiple amalgamated LSTs indicate widespread erosion of the intervening TST and HST deposits. The high proportion of debrites on the bottomsets is ascribed to the trigger mechanisms being collapse at the clinoform rollover, and the short transport distance that limited flow transformation to turbidity currents. Erosion surfaces, dune-scale bedforms, and coarse-grained lags are evidence for sediment bypass in the Site M28 core, which is supported by the interpretation of Site M29 deposits of the same age, suggesting that more turbidite-prone strata will be found basinward of Site M29. A new model is presented for the intermediate-scale, and gravity-driven, clinothems that are of neither deltaic nor basin-margin scale. This was derived from the integrated subsurface data set that demonstrates that (1) large volumes of sediment gravity-flow deposits can accumulate in bottomsets of relatively shallow $(\sim 100-200 \mathrm{~m}$ deep $)$ and low-gradient $\left(\sim 1^{\circ}-4^{\circ}\right)$ intrashelf clinothems, (2) "deepwater" facies can be a significant component of continental shelf successions, and (3) given continental shelf physiography and depths, the formation of similar deposits as part of shelf prism architecture is likely a common scenario through Earth history.

\section{ACKNOWLEDGMENTS}

We thank the drillers and scientists of Integrated Ocean Drilling Program (IODP) Expedition 313 for their enthusiastic collaboration, and the Bremen Core Repository for hosting our studies. We thank C. Lombardi, J. Criscione, and R. Miller for lithologic analyses, and for reviews by lvar. Midtkandal and Cristian Carvajal that helped to refine an earlier version of this paper. Funding was provided 
by the Consortium for Ocean Leadership/U.S. Science Support Program and the National Science Foundation (OCE14-63759) to Miller and Browning, NERC (NE/F001428/1) to Hesselbo, and NERC (NE/HO1430/) to Hodgson, and samples provided by the IODP and the International Continent Scientific Drilling Program (ICDP).

\section{REFERENCES CITED}

Amy, L.A., Kneller, B., and McCaffrey, W.D., 2000, Evaluating the links between turbidite characteristics and gross system architecture: Upscaling insights from the turbidite sheet-system of the Peïra Cava, SE France, in Proceedings, SEPM (Society for Sedimentary Geology) Gulf Coast Section, $20^{\text {th }}$ Annual Research Conference, Deep-Water Reservoirs of the World Houston, Texas, 3-6 December, p. 1-15.

Anell, I., Midtkandal, I., and Braathen, A., 2014, Trajectory analysis and inferences on geometric relationships of an Early Triassic prograding clinoform succession on the northern Barents Shelf: Marine and Petroleum Geology, v. 54, p. 167-179, https://doi.org/10.1016/j.marpetgeo .2014.03.005.

Browning, J.V., Miller, K.G., Sugarman, P.J., Barron, J., McCarthy, F.M.G., Kulhanek, D.K., Katz, M.E., and Feigenson, M.D., 2013, Chronology of Eocene-Miocene sequences on the New Jersey shallow shelf: Implications for regional, interregional, and global correlations: Geosphere, v. 9, p. 1434-1456, https://doi.org/10.1130/GES00857.1

Burgess, P.M., and Hovius, N., 1998, Rates of delta progradation during highstands: Consequences for timing of deposition in deep-marine systems: Journal of the Geological Society, v. 155, p. 217-222, https://doi.org/10.1144/gsggs.155.2.0217.

Burgess, P.M and Prince, G.D, 2015, Non-unique stratal geometries: Implications for sequence stratigraphic interpretations: Basin Research, v. 27, p. 351-365, https://doi.org/10.1111/bre 12082.

Carvajal, C.R., and Steel, R.J., 2006, Thick turbidite successions from supply dominated shelves during sea-level highstand: Geology, v. 34, p. 665-668, https://doi.org/10.1130/G22505.1.

Carvajal, C., and Steel, R., 2009, Shelf-edge architecture and bypass of sand to deep water Influence of sediment supply, sea level, and shelf-edge processes: Journal of Sedimentary Research, v. 79, p. 652-672, https://doi.org/10.2110/js.2009.074.

Carvajal, C., Steel, R., and Petter, A., 2009, Sediment supply: The main driver of shelf-margin growth: Earth-Science Reviews, v. 96, p. 221-248, https://doi.org/10.1016/j.earscirev.2009.06 .008 .

Catuneanu, O., 2006, Principles of Sequence Stratigraphy: Elsevier, Amsterdam, $375 \mathrm{p}$

Christie-Blick, N., and Driscoll, N.W., 1995, Sequence stratigraphy: Annual Review of Earth and Planetary Sciences, v. 23, p. 451-478, https://doi.org/10.1146/annurev.ea.23.050195.002315.

Christie-Blick, N., Austin, J.A., Jr., and Malone, M.J., eds., 2003, Proceedings of the Ocean Drilling Program, Scientific Results, Volume 174A: College Station, Texas, Ocean Drilling Program, https://doi.org/10.2973/odp.proc.sr.174a.2003.

Coe, A.L., ed., 2003, The Sedimentary Record of Sea-Level Change: Cambridge, UK, Cambridge University Press, $288 \mathrm{p}$

Dasgupta, S., and Buatois, L.A., 2012, Unusual occurrence and stratigraphic significance of the Glossifungites ichnofacies in a submarine paleo-canyon-Example from a Pliocene shelfedge delta, Southeast Trinidad: Sedimentary Geology, v. 269-270, p. 69-77, https://doi.or /10.1016/j.sedgeo.2012.06.004

Deptuck, M.E., Piper, D.J., Savoye, B., and Gervais, A., 2008, Dimensions and architecture of late Pleistocene submarine lobes off the northern margin of East Corsica: Sedimentology v. 55, p. 869-898,

Dixon, J.F., Steel, R.J., and Olariu, C., 2012a, River-dominated, shelf-edge deltas: Delivery of sand across the shelf break in the absence of slope incision: Sedimentology, v. 59, p. 1133-1157 https://doi.org/10.1111/j.1365-3091.2011.01298.

Dixon, J.F., Steel, R.J., and Olariu, C., 2012b, Shelf-edge delta regime as a predictor of deep-water deposition: Journal of Sedimentary Research, v. 82, p. 681-687, https://doi.org/10.2110/js .2012 .59 .

Fisher, R.V., 1983, Flow transformations in sediment gravity flows: Geology, v. 11, p. 273-274, https://doi.org/10.1130/0091-7613(1983)11<273:FTISGF>2.0.CO;2

Fongngern, R., Olariu, C., Steel, R.J., and Krézsek, C., 2016, Clinoform growth in a Miocene, Para-tethyan deep lake basin: Thin topsets, irregular foresets and thick bottomsets: Basin Research, v. 28, p. 770-795, https://doi.org/10.1111/bre.12132.
Fulthorpe, CS, and Austin, JA, 1998 , Anatomy of rapid margin progradation: Three-dimensional geometries of Miocene clinoforms, New Jersey margin: The American Association of sional geometries of Miocene clinoforms, New Jerse
Petroleum Geologists Bulletin, v. 82, p. 251-273.

Galloway, W.E., 1989, Genetic stratigraphic sequences in basin analysis I: Architecture and genesis of flooding-surface bounded depositional units: The American Association of Petroleum Geologists Bulletin, v. 73, p. 125-142.

Greenlee, S.M., Devlin, W.J., Miller, K.G., Mountain, G.S., and Flemings, P.B., 1992, Integrated sequence stratigraphy of Neogene deposits, New Jersey continental shelf and slope: Com parison with the Exxon model: Geological Society of America Bulletin, v. 104, p. 1403-1411, https://doi.org/10.1130/0016-7606(1992)104<1403:ISSOND>2.3.CO;2.

Grundvåg, S.A., Johannessen, E.P., Helland-Hansen, W., and Plink-Björklund, P., 2014, Depositional architecture and evolution of progradationally stacked lobe complexes in the Eocene Centr Basin of Spitsbergen: Sedimentology, v. 61, p. 535-569, https://doi.org/10.1111/sed.12067.

Gugliotta, M., Kurcinka, C.E., Dalrymple, R.W., Flint, S.S., and Hodgson, D.M., 2016, Decoupling seasonal fluctuations in fluvial discharge from the tidal signature in ancient deltaic deposits: An example from the Neuquén Basin, Argentina: Journal of the Geological Society, v. 173, p. 94-107, https://doi.org/10.1144/jgs2015-030

Hathaway, J.C., Poag, C.W., Valentine, P.C., Miller, R.E., Schultz, D.M., Manheim, R.T., Kohout, F.A., Bothner, M.H., and Sangrey, D.A., 1979, U.S. Geological Survey core drilling on the Atlantic shelf: Science, v. 206, p. 515-527, https://doi.org/10.1126/science.206.4418.515

Haughton, P., Davis, C., McCaffrey, W., and Barker, S., 2009, Hybrid sediment gravity flow deposits: Classification, origin and significance: Marine and Petroleum Geology, v. 26, p. 19001918, https://doi.org/10.1016/j.marpetgeo.2009.02.012

elland-Hansen, W., and Hampson, G.J., 2009, Trajectory analysis: Concepts and applications: Basin Research, v. 21, p. 454-483, https://doi.org/10.1111/j.1365-2117.2009.00425.X.

Helland-Hansen, W., Steel, R.J., and Sømme, T.O., 2012, Shelf genesis revisited: Journal of Sedmentary Research, v. 82, p. 133-148, https://doi.org/10.2110/js.2012.15.

Henriksen, S., Hampson, G.J., Helland-Hansen, W., Johannessen, E.P., and Steel, R.J., 2009, Shelf edge and shoreline trajectories, a dynamic approach to stratigraphic analysis: Basin Research, v. 21, p. 445-453, https://doi.org/10.1111/j.1365-2117.2009.00432.x.

Hesselbo, S.P., and Huggett, J.M., 2001, Glaucony in ocean-margin sequence stratigraphy (Oligocene-Pliocene, offshore New Jersey, U.S.A.; ODP Leg 174a): Journal of Sedimentary Research, v. 71, p. 599-607, https://doi.org/10.1306/112800710599.

Hodgson, D.M., 2009, Distribution and origin of hybrid beds in sand-rich submarine fans of the Tanqua depocentre, Karoo Basin, South Africa: Marine and Petroleum Geology, v. 26, p. 1940-1956, https://doi.org/10.1016/j.marpetgeo.2009.02.011.

odgson, D.M., Kane, I.A., Flint, S.S., Brunt, R.L., and Ortiz-Karpf, A., 2016, Time-transgressive confinement on the slope and the progradation of basin-floor fans: Implications for the sequence stratigraphy of deep-water deposits: Journal of Sedimentary Research, v. 86, p. 7386, https://doi.org/10.2110/jsr.2016.3.

Hubbard, S.M., and Shultz, M.R., 2008, Deep burrows in submarine fan-channel deposits of the Cerro Toro Formation (Cretaceous), Chilean Patagonia: Implications for firmground development and colonization in the deep sea: Palaios, v. 23, p. 223-232, https://doi.org/10.2110 /palo.2006.p06-127r.

Inwood, J., Lofi, J., Davies, S., Basile, C., Bjerum, C., Mountain, G., Proust, J.N., Otsuka, H., and Valppu, H., 2013, Statistical classification of log response as an indicator of facies variation during changes in sea level: Integrated Ocean Drilling Program Expedition 313: Geosphere, v. 9, p. 1025-1043, https://doi.org/10.1130/GES00913.1.

Johannessen, E.P., and Steel, R.J., 2005, Shelf-margin clinoforms and prediction of deepwate sands: Basin Research, v. 17, p. 521-550, https://doi.org/10.1111/j.1365-2117.2005.00278.x.

Jones, G.E.D., Hodgson, D.M., and Flint, S.S., 2013, Contrast in the process response of stacked clinothems to the shelf-slope rollover: Geosphere, v. 9, p. 299-316, https://doi.org/10.1130 /GES00796.1.

Jones, G.E.D., Hodgson, D.M., and Flint, S.S., 2015, Lateral variability in clinoform trajectory, process regime, and sediment dispersal patterns beyond the shelf-edge rollover in exhumed basin margin-scale clinothems: Basin Research, v. 27, p. 657-680, https://doi.org/10.1111/bre .12092

Katz, M.E., Browning, J.V., Miller, K.G., Monteverde, D., Mountain, G.S., and Williams, R.H., 2013, Paleobathymetry and sequence stratigraphic interpretations from benthic foraminifera: Insights on New Jersey shelf architecture, IODP Expedition 313: Geosphere, v. 9, p. 1488-1513, https://doi.org/10.1130/GES00872. 
Kominz, M.A., Miller, K.G., Browning, J.V., Katz, M.E., and Mountain, G.S., 2016, Miocene relative sea level on the New Jersey shallow continental shelf and coastal plain derived from one-dimensional backstripping: A case for both eustasy and epeirogeny: Geosphere, v. 12 p. 1437-1456, https://doi.org/10.1130/GES01241.1.

Koo, W.M., Olariu, C., Steel, R.J., Olariu, M.I., Carvajal, C.R., and Kim, W., 2016, Coupling between shelf-edge architecture and submarine-fan growth style in a supply-dominated margin: Journal of Sedimentary Research, v. 86, p. 613-628, https://doi.org/10.2110/jsr.2016.42.

Locat, J., and Lee, H.J., 2005, Subaqueous debris flows, in Jakob, M., and Hungr, O., eds., DebrisFlow Hazards and Related Phenomena: Berlin Heidelberg, Springer, p. 203-245, https://do .org/10.1007/3-540-27129-5_9

Martinsen, O.J., and Helland-Hansen, W., 1995, Strike variability of clastic depositional systems Does it matter for sequence-stratigraphic analysis?: Geology, v. 23, p. 439-442, https://do .org/10.1130/0091-7613(1995)023<0439:SVOCDS >2.3.CO;2.

McHugh, C.M., Damuth, J.E., and Mountain, G.S., 2002, Cenozoic mass-transport facies and their correlation with relative sea-level change, New Jersey continental margin: Marine Geology v. 184, p. 295-334, https://doi.org/10.1016/S0025-3227(01)00240-7.

Mellere, D., Plink-Björklund, P., and Steel, R., 2002, Anatomy of shelf deltas at the edge of a prograding Eocene shelf margin, Spitsbergen: Sedimentology, v. 49, p. 1181-1206, https:/ doi.org/10.1046/j.1365-3091.2002.00484.x.

Miller, K.G., and Snyder, S.W., eds., 1997, Proceedings of the Ocean Drilling Program, Scientific Results, Volume 150X: College Station, Texas, Ocean Drilling Program, $388 \mathrm{p}$

Miller, K.G., Rufolo, S., Sugarman, P.J., Pekar, S.F, Browning, J.V., and Gwynn, D.W., 1997, Early to middle Miocene sequences, systems tracts, and benthic foraminiferal biofacies, New Jersey coastal plain, in Miller, K.G., and Snyder, S.W., eds., Proceedings of the Ocean Drilling Program, Scientific Results, Volume 150X: College Station, Texas, Ocean Drilling Program, p. 169-186.

Miller, K.G., Kominz, M.A., Browning, J.V., Wright, J.D., Mountain, G.S., Katz, M.E., Sugarman P.J., Cramer, B.S., Christie-Blick, N., and Pekar, S.F., 2005, The Phanerozoic record of global sea-level change: Science, v. 310, p. 1293-1298, https://doi.org/10.1126/science.1116412.

Miller, K.G., Mountain, G.S., Browning, J.V., Katz, M.E., Monteverde, D., Sugarman, P.J., Ando, H., Bassetti, M.A., Bjerrum, C.J., Hodgson, D., and Hesselbo, S., 2013a, Testing sequence stratigraphic models by drilling Miocene foresets on the New Jersey shallow shelf: Geosphere, v. 9, p. 1236-1256, https://doi.org/10.1130/GES00884.

Miller, K.G., Browning, J.V., Mountain, G.S., Bassetti, M.A., Monteverde, D., Katz, M.E., Inwood J., Lofi, J., and Proust, J.-N., 2013b, Sequence boundaries are impedance contrasts: Coreseismic-log integration of Oligocene-Miocene sequences, New Jersey shallow shelf: Geosphere, v. 9, p. 1257-1285, https://doi.org/10.1130/GES00858.1

Mitchum, R.M., Jr., Vail, P.R., and Thompson, S., III, 1977, Seismic stratigraphy and global changes of sea level: Part 2. The depositional sequence as a basic unit for stratigraphic analysis, in Payton, C.E., ed., Seismic Stratigraphy: Applications to Hydrocarbon Exploration: American Association of Petroleum Geologists Memoir 26, p. 53-62.

Monteverde, D.H., 2008, Sequence stratigraphic analysis of early and middle Miocene shelf progradation along the New Jersey margin [Ph.D. thesis]: New Brunswick, New Jersey, Rutgers University, $247 \mathrm{p}$.

Monteverde, D.H., Mountain, G.S., and Miller, K.G., 2008, Early Miocene sequence development across the New Jersey margin: Basin Research, v. 20, p. 249-267, https://doi.org/10.1111/] $.1365-2117.2008 .00351 . x$

Mountain, G.S., and Monteverde, D.H., 2012, If you've got the time, we've got the depth: The importance of accurate core-seismic correlation: Abstract PP51B-2111 presented at the American Geophysical Union Fall Meeting, San Francisco, California, 3-7 December.

Mountain, G.S., Miller, K.G., Blum, P., et al., 1994, Proceedings of the Ocean Drilling Program Initial Reports, Volume 150: College Station, Texas, Ocean Drilling Program, 885 p.

Mountain, G.S., Proust, J.-N., McInroy, D., and Cotterill, C., and the Expedition 313 Scientists, 2010 Proceedings of the Integrated Ocean Drilling Program, Volume 313: Tokyo, Integrated Ocean Drilling Program Management International, Inc., https://doi.org/10.2204/iodp.proc.313.2010. Mulder, T., and Alexander, J., 2001, The physical character of subaqueous sedimentary density
flows and their deposits: Sedimentology, v. 48, p. 269-299, https://doi.org/10.1046/j.1365 $-3091.2001 .00360$.

Mulder, T., Syvitski, J.P., Migeon, S., Faugeres, J.C., and Savoye, B., 2003, Marine hyperpycnal flows: Initiation, behavior and related deposits. A review: Marine and Petroleum Geology, v. 20, p. 861-882, https://doi.org/10.1016/j.marpetgeo.2003.01.003.
Neal, J., and Abreu, V., 2009, Sequence stratigraphy hierarchy and the accommodation succession method: Geology, v. 37, p. 779-782, https://doi.org/10.1130/G25722A.1.

Ison, C.H., Karabanov, E.B., Colman, S.M., and Escutia, C., 1999, Tectonic and sediment supply control of deep rift lake turbidite systems: Lake Baikal, Russia: Geology, v. 27, p. 163-166, https://doi.org/10.1130/0091-7613(1999)027<0163:TASSCO>2.3.CO;2.

Nittrouer, C.A., Kuehl, S.A., Figueiredo, A.G., Allison, M.A., Sommerfield, C.K., Rine, J.M., Faria, L.E.C., and Silveira, O.M., 1996, The geological record preserved by Amazon shelf sedimentation: Continental Shelf Research, v. 16, p. 817-841, https://doi.org/10.1016/0278-4343 (95)00053-4.

Omosanya, K.O., and Alves, T.M., 2013, A 3-dimensional seismic method to assess the provenance of Mass-Transport Deposits (MTDs) on salt-rich continental slopes (Espírito Santo Basin, SE Brazil): Marine and Petroleum Geology, v. 44, p. 223-239, https://doi.org/10.1016/ marpetgeo.2013.02.006.

Paris, P.J., Walsh, J.P., and Corbett, D.R., 2016, Where the continent ends: Geophysical Research Letters, v. 43, p. 12,208-12,216, https://doi.org/10.1002/2016GL071130.

Patruno, S., Hampson, G.J., and Jackson, C.A., 2015, Quantitative characterisation of deltaic and subaqueous clinoforms: Earth-Science Reviews, v. 142, p. 79-119, https://doi.org/10.1016/ .earscirev.2015.01.004

Pellegrini, C., Maselli, V., Gamberi, F., Asioli, A., Bohacs, K.M., Drexler, T.M., and Trincardi, F., 2017, How to make a 350-m-thick lowstand systems tract in 17,000 years: The Late Pleistocene Po River (Italy) lowstand wedge: Geology, v. 45, p. 327-330, https://doi.org/10.1130/G38848.1.

Peltier, W.R., and Fairbanks, R.G., 2006, Global glacial ice volume and Last Glacial Maximum duration from an extended Barbados sea level record: Quaternary Science Reviews, v. 25, p. 3322-3337, https://doi.org/10.1016/j.quascirev.2006.04.010.

etter, A.L., and Steel, R.J., 2006, Hyperpycnal flow variability and slope organization on an Eocene shelf margin, Central Basin, Spitsbergen: The American Association of Petroleum Geologists Bulletin, v. 90, p. 1451-1472, https://doi.org/10.1306/04240605144.

Piper, D.J., and Normark, W.R., 2009, Processes that initiate turbidity currents and their influence on turbidites: A marine geology perspective: Journal of Sedimentary Research, v. 79, p. $347-362$, https://doi.org/10.2110/jsr.2009.046.

Pink-Björklund, P., and Steel, R., 2002, Sea-level fall below the shelf edge, without basin-floor fans: Geology, v. 30, p. 115-118, https://doi.org/10.1130/0091-7613(2002)030<0115:SLFBTS>2.0.CO;2.

Plink-Bjorklund, P., and Steel, R.J., 2004, Initiation of turbidity currents: Outcrop evidence for Eocene hyperpycnal flow turbidites: Sedimentary Geology, v. 165, p. 29-52, https://doi.org /10.1016/j.sedgeo.2003.10.013

Plint, A.G., and Nummendal, D., 2000, The falling stage systems tract: Recognition and importance in sequence stratigraphic analysis, in Hunt, D., and Gawthorpe, R.L., eds., Sedimentary Responses to Forced Regression: Geological Society of London Special Publication 172, p. 1-17, https://doi.org/10.1144/GSL.SP.2000.172.01.01.

oag, C.W., 1985, Depositional history and stratigraphic reference section for central Baltimore Canyon trough, in Poag, C.W., ed., Geologic Evolution of the United States Atlantic Margin New York, Van Nostrand Reinhold, p. 217-263.

Posamentier, H.W., and Vail, P.R., 1988, Eustatic controls on clastic deposition II-Sequence and systems tract models, in Wilgus, C.K., Hastings, B.S., Posamentier, H., Van Wagoner, J., Ross, C.A., and Kendall, C.G.St.C., eds., Sea-Level Changes: An Integrated Approach: Society of Economic Paleontologists and Mineralogists Special Publication 42, p. 125-154, https://doi.org/10.2110/pec.88.01.0125.

Posamentier, H.W., Jervey, M.T., and Vail, P.R., 1988, Eustatic controls on clastic deposition I-Conceptual framework, in Wilgus, C.K., Hastings, B.S., Posamentier, H., Van Wagoner, J., Ross, C.A., and Kendall, C.G.St.C., eds., Sea-Level Changes: An Integrated Approach: Society of Economic Paleontologists and Mineralogists Special Publication 42, p. 109-124, https://doi.org/10.2110/pec.88.01.0109.

Poyatos-Moré, M., Jones, G.D., Brunt, R.L., Hodgson, D.M., Wild, R.J., and Flint, S.S., 2016 Mud-dominated basin margin progradation: Processes and implications: Journal of Sedimentary Research, v. 86, p. 863-878, https://doi.org/10.2110/jsr.2016.57.

Prélat, A., Hodgson, D.M., and Flint, S.S., 2009, Evolution, architecture and hierarchy of distributary deep-water deposits: A high-resolution outcrop investigation from the Permian Karoo Basin, South Africa: Sedimentology, v. 56, p. 2132-2154, https://doi.org/10.1111/j.1365-3091 .2009.01073.x.

Prélat, A., Pankhania, S.S., Jackson, C.A.-L., and Hodgson, D.M., 2015, Slope gradient and lithology as controls on the initiation of submarine slope gullies: Insights from the North Car- 
narvon Basin, Offshore NW Australia: Sedimentary Geology, v. 329, p. 12-17, https://doi.org /10.1016/j.sedgeo.2015.08.009.

Reynolds, D.J., Steckler, M.S., and Coakley, B.J., 1991, The role of the sediment load in sequence stratigraphy: The influence of flexural isostasy and compaction: Journal of Geophysical Re search. Solid Earh, v. 96, p. 6931-6949, hips:/doi.org/0.1029:00JB01914.

Rich, J.L., 1951, Three critcal environments of deposition, and criteria for recognition of rocks deposited in each of them: Geological Society of America Bulletin, v. 62, p. 1-20, https://do .org/10.11300016-760G

Savrda, C.E., Browning, J.V., Krawinkel, H., and Hesselbo, S.P., 2001, Firmground ichnofabrics in deep-water sequence stratigraphy, Tertiary clinoform-toe deposits, New Jersey slope: Palaios, v. 16, p. 294-305, htps//doi.org/10.1669/0883-1351(2001)016<0294:FIIDWS >2. $\mathrm{CO} ; 2$

Schlee, J.S., 1981, Seismic stratigraphy of Baltimore Canyon Trough: The American Association of Petroleum Geologists Bulletin, v. 65, p. 26-53.

Steckler, M.S., Mountain, G.S., Miller, K.G., and Christie-Blick, N., 1999, Reconstruction of Tertiary progradation and clinoform development on the New Jersey passive margin by 2-D backstripping: Marine Geology, v. 154, p. 399-420, https://doi.org/10.1016/50025-3227(98)00126-1. Steel, R.J., and Olsen, T., 2002, Clinoforms, clinoform trajectories and deepwater sands, in Armentrout, J.M., and Rosen, N.C., Sequence Stratigraphic Models for Exploration and Production: Evolving Methodology, Emerging Models and Application Histories: Proceeding of the 22nd Annual Bob F. Penkins Research Conference, p. 367-381.

Stevenson, C.J., Jackson, C.A.L., Hodgson, D.M., Hubbard, S.M., and Eggenhuisen, J.T., 2015 Deep-water sediment bypass: Journal of Sedimentary Research, v. 85, p. 1058-1081, https:/ doi.org/10.2110/jsr.2015.63

Strachan, L.J., 2008, Flow transformations in slumps: A case study from the Waitemata Basin New Zealand: Sedimentology, v. 55, p. 1311-1332, https://doi.org/10.1111/j.1365-3091.2007 .00947.x.

Swenson, J.B., Paola, C., Pratson, L., Voller, V.R., and Murray, A.B., 2005, Fluvial and marine controls on combined subaerial and subaqueous delta progradation: Morphodynamic modeling of compound-clinoform development: Journal of Geophysical Research, v. 110, F02013 https://doi.org/10.1029/2004JF000265.

Talling, P.J., 2013, Hybrid submarine flows comprising turbidity current and cohesive debris flow: Deposits, theoretical and experimental analyses, and generalized models: Geosphere, v. 9 p. 460-488, https://doi.org/10.1130/GES00793.

Talling, P.J., Masson, D.G., Sumner, E.J., and Malgesini, G., 2012, Subaqueous sediment density flows: Depositional processes and deposit types: Sedimentology, v. 59, p. 1937-2003, https:// doi.org/10.1111/j.1365-3091.2012.01353.x

Talling, P.J., Paull, C.K., and Piper, D.J., 2013, How are subaqueous sediment density flows triggered, what is their internal structure and how does it evolve? Direct observations from v. 125, p. 244-287, hips/ldioiog/10.1016 /j.earscirev.2013.07.005.
Uroza, C.A., and Steel, R.J., 2008, A highstand shelf-margin delta system from the Eocene of West Spitsbergen, Norway: Sedimentary Geology, v. 203, p. 229-245, https://doi.org/10.1016 j.sedgeo.2007.12.003.

Vail, P.R., 1987, Seismic stratigraphy interpretation using sequence stratigraphy: Part 1. Seismic stratigraphy interpretation procedure, in Bally, A.W., ed., Atlas of Seismic Stratigraphy: American Association of Petroleum Geologists Studies in Geology 27, p. 1-10.

Vail, P.R., Mitchum, R.M., Jr, and Thebal changes of sea level: Part 4. Global cycles of relative changes of sea level, in Payton, C.E., ed., Seismic Stratigraphy: Applications to Hydrocarbon Exploration. American Association of Petroleum Geologists Memoir 26, p. 83-97.

in in marginal-marine systems: Bridging the gap between sedimentology and sequence stratigraphy: The American Association of Petroleum Geologists Bulletin, v. 97, p. 1121-116 https://doi.org/10.1306/11011212024.

an der Merwe, W.C., Flint, S.S., and Hodgson, D.M., 2010, Sequence stratigraphy of an argillaceous, deepwater basin-plain succession: Vischkuil Formation (Permian), Karoo Basin, South Africa: Marine and Petroleum Geology, v. 27, p. 321-333, https://doi.org/10.1016/ marpetgeo.2009.10.007.

van der Merwe, W.C., Hodgson, D.M., Brunt, R.L., and Flint, S.S., 2014, Depositional architecture of sand-attached and sand-detached channel-lobe transition zones on an exhumed stepped slope mapped over a 250 km2 and GES01035.1.

Wagoner, J.C., Mitchum, R.M., Jr., Posamentier, H.W., and Vail, P.R., 1987, Seismic stratigraphy interpretation using sequence stratigraphy: Part 2. Key definitions of sequence stratigraphy, in Bally, A.W., ed., Atlas of Seismic Stratigraphy: American Association of Petroleum Geologists Studies in Geology 27, p. 11-14.

Van Wagoner, J.C., Posamentier, H.W., Mitchum, R.M., Vail, P.R., Sarg, J.F., Loutit, T.S., and Hardenbol, J., 1988, An overview of the fundamentals of sequence stratigraphy and key definitions, in Wilgus, C.K., Hastings, B.S., Posamentier, H., Van Wagoner, J., Ross, C.A., and Kendall, C.G.St.C., eds., Sea-Level Changes: An Integrated Approach: Society of Economic Paleontologists and Mineralogists Special Publication 42, p. 39-45, htps.//doi.org/10.2110/pec.88.01.0039. Wats, A.B., and Steckler, M.S., 1979, Subsidence and eustasy at the continental margin of eastern North America, in Talwani, M., Hay, W., and Ryan, W.B.F, eds., Deep Drilling Results in the Atlantic Ocean: Continental Margins and Paleoenvironment: American Geophysical Union Maurice Ewing Series 3, p. 218-234, htps./dolorg/10.1029/ME003p0218.

ild, R., Fint, S.S., and Hodgson, D.M., 2009, Stratigraphic evolution of the upper slope and shelf edge in the Karoo Basin, South Africa: Basin Research, v. 21, p. 502-527, https://doi.org 10.1111/.1365-2117.2009.00409.x.

ithjack, M.O., Schlische, R.W., and Olsen, P.E., 1998, Diachronous rifting, drifting, and inversion on the passive margin of central eastern North America: AN analog for other passive margins: The American Association of Petroleum Geologists Bulletin, v. 82, p. 817-835. 